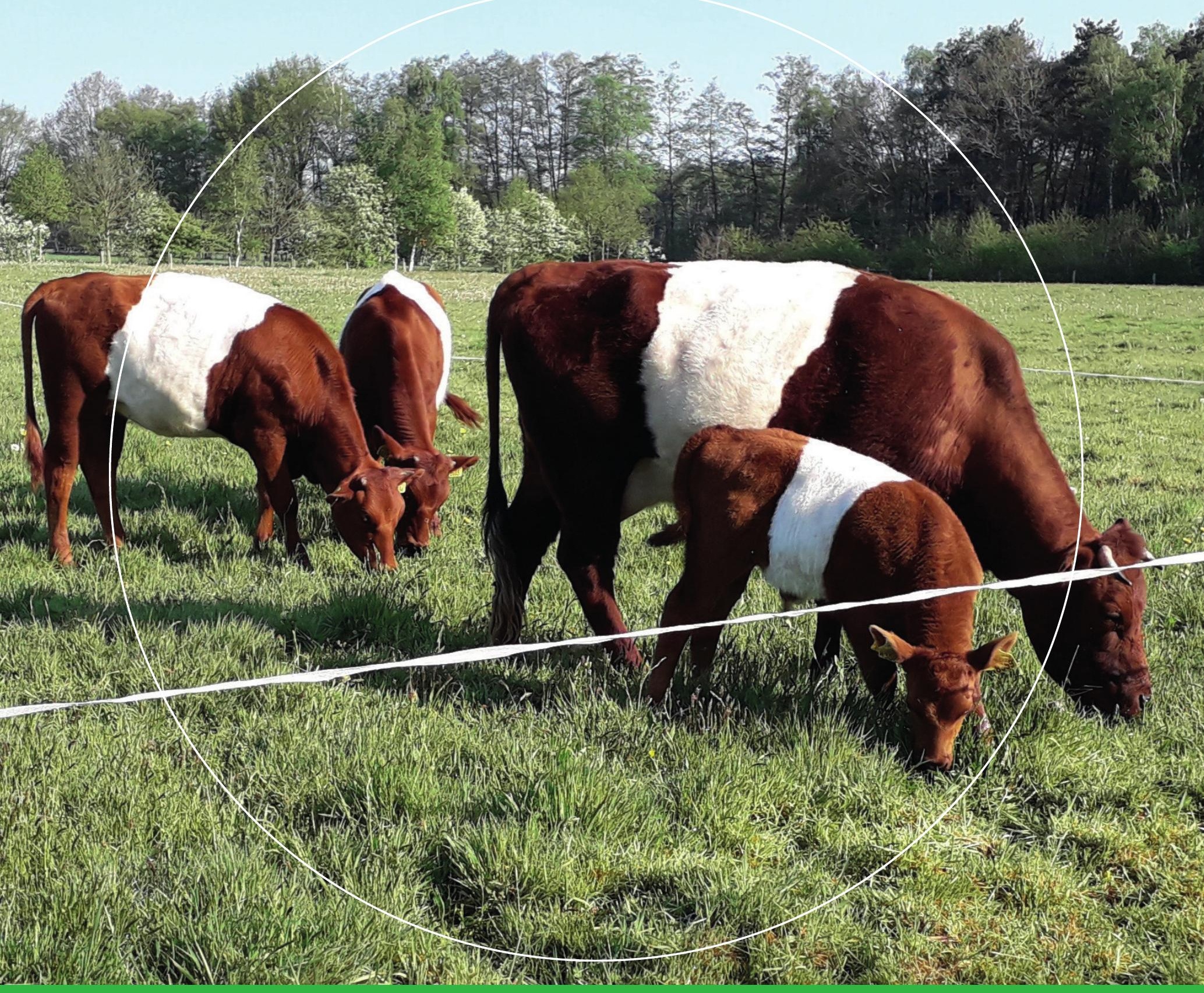

\title{
Effect van mobiele begrazing door koeien en kippen op kruidenrijk grasland op zandgrond
}

Wieger Wamelink, Friso van der Zee \& Marcel Vijn 



\section{Wetenschapswinkel}

\section{Effect van mobiele begrazing door koeien en kippen op kruidenrijk grasland op zandgrond}




\section{Colofon}

$\begin{array}{ll}\text { Titel } & \begin{array}{l}\text { Effect van mobiele begrazing door koeien en kippen op kruidenrijk } \\ \text { grasland op zandgrond } \\ \text { extensieve beweiding, kruidenrijk grasland, kippen, koeien }\end{array} \\ \text { Keywords } & \text { extensive grazing, herb-rich grassland, chickens, cows } \\ \text { Opdrachtgever } & \text { Met Natuur Mee } \\ \text { Projectuitvoering } & \text { Wieger Wamelink, Friso van der Zee \& Marcel Vijn } \\ \text { Projectcoördinatie } & \text { Marcel Vijn } \\ \text { Financiële ondersteuning } & \text { Wageningen Wetenschapswinkel } \\ \text { Begeleidingscommissie } & \text { Lèneke Pfeiffer } \\ \text { Jan Rinze van der Schoot } & \text { Arnold van der Leij } \\ \text { Sanne Beld } \\ \text { Kees van Veluw } \\ \text { Marcel Horsthuis } \\ \text { Elke Kunen } \\ \text { Jacob van der Weele } \\ \text { Reinder Siebinga } \\ \text { Frits Overweg } \\ \text { Eva Vos }\end{array}$

Fotoverantwoording

Vormgeving

Druk

Bronvermelding

ISBN

DOI
De foto's, kaartjes en figuren zijn vervaardigd door de auteurs of de meewerkende studenten, tenzij anders aangegeven Wageningen University \& Research, Communication Services RICOH, 's-Hertogenbosch Verspreiding van het rapport en overname van gedeelten eruit worden aangemoedigd, mits voorzien van deugdelijke bronvermelding ISBN: 978-94-6395-780-9

DOI: https://doi.org/10.18174/545459

Wageningen, Wetenschapswinkel rapport 372 
Effect van mobiele begrazing door koeien en kippen op kruidenrijk grasland op zandgrond

Rapportnummer 372

Wieger Wamelink, Friso van der Zee \& Marcel Vijn

Wageningen, juni 2021

Met Natuur Mee

Wageningen Plant Research

Postbus 430

8200 AK Lelystad

0320291111

Wageningen Environmental Research

Postbus 47

6700 AA Wageningen

0317481700

\section{Wageningen University \& Research Wetenschapswinkel}

Postbus 9101

6700 HB Wageningen

(0317) 483908

wetenschapswinkel@wur.nl
Met Natuur Mee praktiseert, ontwikkelt en promoot een regeneratieve (veerkrachtige) landbouw met positief effect op biodiversiteit en het klimaat.

Wageningen Plant Research (WPR) is onderdeel van Wageningen University \& Research. Binnen WPR doet Open Teelten onderzoek naar duurzame landbouwsystemen.

Wageningen Environmental Research is onderdeel van Wageningen University \& Research. Wageningen Environmental Research biedt een combinatie van toegepast en wetenschappelijk onderzoek in een veelheid van expertisevelden op het gebied van de groene ruimte en het gebruik ervan.

Maatschappelijke organisaties zoals verenigingen en belangengroepen, die niet over voldoende financiële middelen beschikken, kunnen met onderzoeksvragen terecht bij de Wageningen Wetenschapswinkel. Deze biedt ondersteuning bij de realisatie van onderzoeksprojecten. Aanvragen moeten aansluiten bij de werkgebieden van Wageningen University \& Research: duurzame landbouw, voeding en gezondheid, een leefbare groene ruimte en maatschappelijke veranderingsprocessen. 


\section{Inhoud}

$\begin{array}{lr}\text { Voorwoord } & 7\end{array}$

$\begin{array}{lr}\text { Samenvatting } & 9\end{array}$

$\begin{array}{lr}\text { Summary } & 11\end{array}$

$1 \quad$ Inleiding $\quad 13$

$\begin{array}{llr}1.1 & \text { Aanleiding } & 13\end{array}$

$\begin{array}{llr}1.2 & \text { Doel van het onderzoek } & 13\end{array}$

2 Materiaal \& Methode $r$

$\begin{array}{lll}2.1 & \text { Opzet vegetatieopnamen en bodemmonstername } & 15\end{array}$

$\begin{array}{llr}2.2 & \text { Vegetatieopnamen } & 17\end{array}$

$\begin{array}{llr}2.3 & \text { Bodemmonstername } & 17\end{array}$

3 Resultaten $r$

$\begin{array}{llr}3.1 & \text { Algemene indruk van het perceel } & 19\end{array}$

$\begin{array}{lll}3.2 & \text { Vegetatieopnamen } & 23\end{array}$

$\begin{array}{lll}3.3 & \text { Belangrijkste verschillen tussen de vegetatieopnamen } & 24\end{array}$

$\begin{array}{lll}3.4 & \text { Bodemfauna } & 26\end{array}$

$\begin{array}{llr}3.5 & \text { Chemische bodemanalyses } & 27\end{array}$

4 Discussie \& Conclusies $\quad 33$

$\begin{array}{lll}4.1 & \text { Vegetatie } & 33\end{array}$

$\begin{array}{lll}4.2 & \text { Bodemfauna } & 33\end{array}$

$\begin{array}{lll}4.3 & \text { Chemie } & 33\end{array}$

$\begin{array}{llr}4.4 & \text { Eindconclusies } & 34\end{array}$

$5 \quad$ Toekomstvisie $\quad 35$

Bijlage 1 Waarnemingen van bodemdieren per monster 37

$\begin{array}{llr}\text { Bijlage } 2 & \text { Vegetatieopnamen } & 39\end{array}$

Bijlage 3 Bodemanalyses per monsterpunt en gemiddelde per behandeling 41 


\section{Voorwoord}

In 2017 maakte ik kennis met het gedachtengoed van Allan Savory (savory.global). Ik zag en zie de potentie van dit begrazingsbeheer voor het veerkrachtiger maken van kruidenrijke graslanden op droge zandgronden in Nederland.

Klimaatverandering, biodiversiteitsverlies en de overige nadelige effecten van de gangbare landbouw vragen om een aangepast beheer. Eenzijdig maaien en afvoeren van gras van hooggelegen zandgronden in combinatie met standbeweiding is vaker niet dan wel toereikend op deze gronden. Ik vermoed dat binnen de kruidenrijke graslanden de droge zandgronden gemiddeld genomen juist kwetsbaarder worden door dit eenzijdige beheer.

Daar komt bij dat er doorgaans minder aandacht naar deze veelvoorkomende kruidenrijke graslanden gaat omdat natuurbeheerders grotere gebieden onder zich hebben gekregen en tegelijkertijd meer administratie te verwerken krijgen. Ook de gemiddelde boer die dit type graslanden pacht heeft zijn focus niet op het verbeteren van de gezondheid van deze gronden, uitzonderingen daargelaten.

In 2018 zijn Lèneke Pfeiffer en Marcel Vijn op bezoek geweest bij het kruidenrijke grasland dat onderwerp is van dit rapport. Dit perceel is gelegen in de gemeente Haaksbergen en eigendom van Staatsbosbeheer. Marcel en Lèneke gingen akkoord met de wetenschapswinkelaanvraag om mobiel geplande begrazing te onderzoeken voor een duurzaam klimaatbestendig beheer van kruidenrijke graslanden op zandgronden.

Ik wil Wim Schippers, Marcel Vijn, Lèneke Pfeiffer, Wieger Wamelink, Friso van der Zee, Adriaan Hollander, Marcel Horsthuis en alle betrokken WUR studenten bedanken voor hun betrokkenheid.

Sanne Beld, Met Natuur Mee

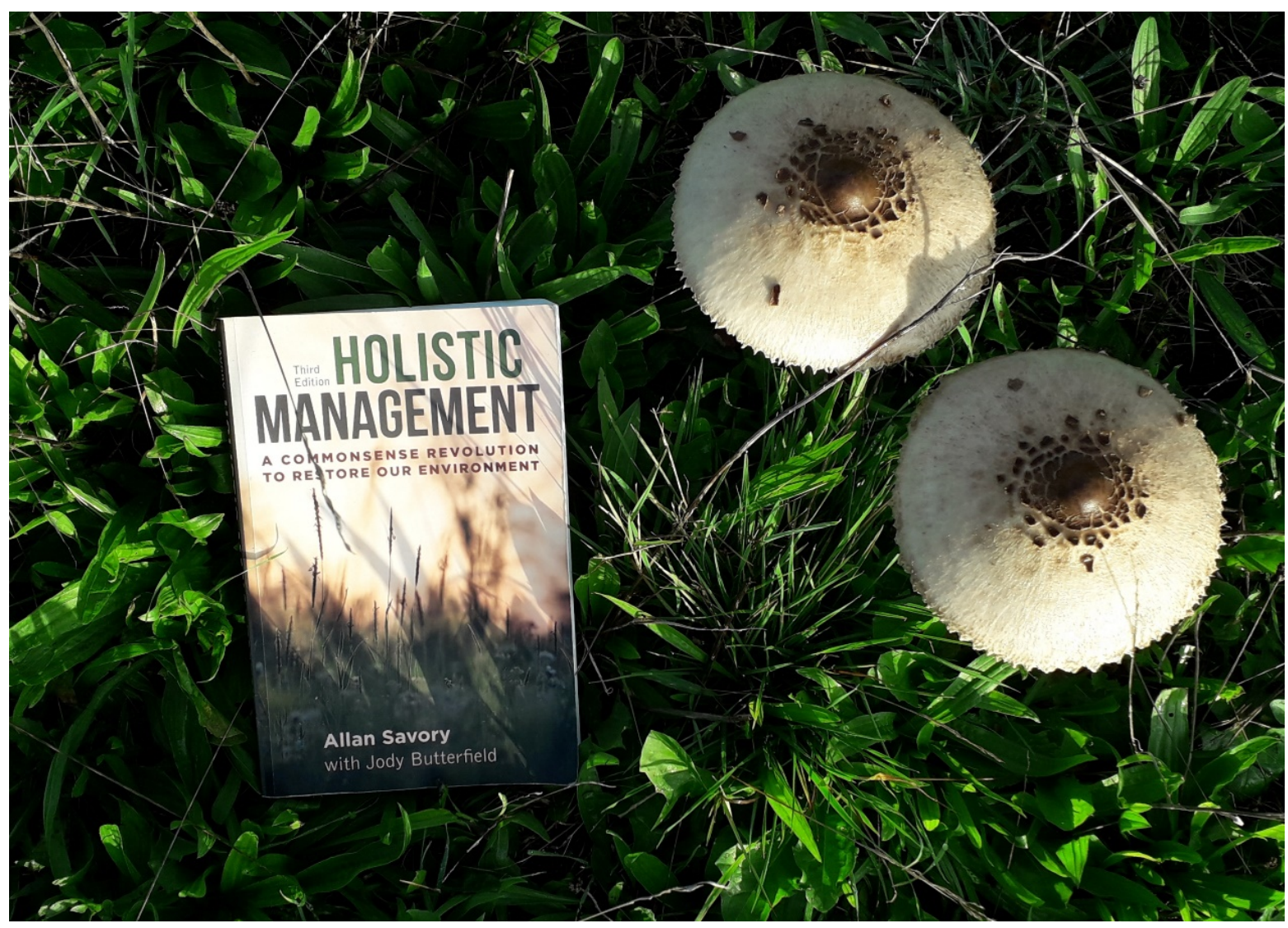




\section{Samenvatting}

Met Natuur Mee, van initiatiefnemer Sanne Beld, praktiseert, ontwikkelt en promoot een regeneratieve (veerkrachtige) landbouwmethode geïnspireerd door ervaringen in het buitenland (Joel Salatin, Allan Savory etc.). Samen met haar partners en vrijwilligers wil Met natuur Mee een voorloperslocatie ontwikkelen voor veerkrachtige landbouw, inspiratie bieden aan jonge boeren, kennisdelen, onderzoek doen maar bovenal een voedzame oogst bieden die mensen weer met het landschap verbindt.

In dit onderzoek gaan Wageningse wetenschappers op zoek naar antwoord op de vraag: Wat is het effect van mobiel beweidingsbeheer met koeien en kippen op kruidenrijk grasland op droge zandgrond? Wat doet dit boven en onder de grond qua bodemleven, vochthuishouding en soortenrijkdom van de vegetatie? Dat doen we door de effecten van het beheer op het huidige perceel dat Met Natuur Mee pacht van Staatsbosbeheer in de buurt van Haaksbergerveen in kaart te brengen.

Het beheer van het weiland bestond in 2019 en 2020 uit extensieve begrazing door lakenvelders en kortdurende (1 dag) intensieve begrazing door vleeskippen. Dit was nog niet het optimale mobiele beheer, aangezien er nog te weinig koeien waren om deze mobiele begrazing volgens plan uit te voeren. Het effect van deze vorm van drukbegrazing door kippen op de vegetatie en de bodem is nog (vrijwel) onbekend. Daarom is er een wetenschapswinkel project uitgevoerd waarbij onderzocht is wat het effect van de begrazing is op de vegetatie, bodemleven (vooral wormen) en de chemische samenstelling van de bodem. Als controle perceel is een weiland in de buurt gebruikt dat al langjarig extensief wordt beheerd (standbegrazing door een laag aantal ossen, afgewisseld met 1 maaibeurt per jaar). Op het moment van monstername was het veld nog erg droog na een lange droge periode in voorjaar en zomer van 2020. Dat heeft invloed gehad op het bodemleven en de inventarisatie daarvan, er werden zeer weinig regenwormen en ander macrobodemleven aangetroffen. De verschillen tussen de behandelingen was ook gering, hoewel de plekken met kippenbegrazing in 2019 soortenrijker leken.

De vegetatie laat ook weinig verschillen zien, ook al lijkt er een nat droog gradiënt aanwezig die samenvalt met de hoogteligging van het terrein. Er komen eigenlijk alleen algemene graslandsoorten voor in het veld en het voldoet nog niet aan de wens voor een bloemrijk grasland. Om dat te bereiken zal er zaad van elders moeten worden aangevoerd, bijvoorbeeld via maaisel van een soortenrijk perceel.

De chemische analyses laten zien dat het een behoorlijk voedselarm terrein is en in ieder geval voedselarmer dan een 'normaal' boerenweiland. De zuurgraad van de bodem is laag, wat ook al was geconstateerd op basis van de soortensamenstelling; de bodem is oppervlakkig verzuurd. Daarom wordt geadviseerd om te bekalken. Ook was de vegetatie aan het vervilten, wat ongunstig is voor een soortendivers grasland. Een iets intensievere begrazing kan dit voorkomen. Dit zal worden uitgevoerd vanaf 2021.

De begrazingsperiode door de kippen is nog kort geweest en de begrazing zou langer moeten lopen om daadwerkelijk effecten te kunnen verwachten. 


\section{Summary}

Met Natuur Mee, founded by Sanne Beld, practices, develops and promotes a regenerative (resilient) agricultural method inspired by experiences abroad (Joel Salatin, Allan Savory, etc.). Together with its partners and volunteers, Met Natuur Mee wants to develop a pioneering location for resilient agriculture, offer inspiration to young farmers, share knowledge, conduct research, but above all offer a nutritious harvest that reconnects people with the landscape.

In this study, Wageningen scientists are looking for an answer to the question: What is the effect of mobile grazing management with cows and chickens on herb-rich grassland on dry sandy soil? What does this do above and below the ground in terms of soil life, moisture balance and the diversity of the vegetation? We do this by mapping the effects of the management on the current land that Met Natuur Mee leases from Staatsbosbeheer near Haaksbergerveen.

In 2019 and 2020, the management of the pasture consisted of extensive grazing by cattle and shortterm ( 1 day) intensive grazing by broilers. The management was not yet optimal, due to a shortage in cows. The effect of this form of intense grazing by chickens on the vegetation and the soil is still (relatively) unknown. That is why a science shop project was carried out to investigate the effect of grazing on the vegetation, soil life (especially worms) and the chemical composition of the soil. A nearby meadow has been used as a control plot that has been extensively managed for many years (grazing by a limited number of oxes, combuned with mowing once a year). At the time of sampling, the field was still very dry after a long dry period in the spring and summer of 2020 . This had an impact on the soil life and its inventory, very few earthworms and other macro soil life were found. The differences between the treatments were also minor, although the 2019 chicken grazing areas appeared to be more species-rich.

The vegetation also shows few differences, even though there appears to be a wet dry gradient that coincides with the elevation of the terrain. In fact, only general grassland species occur in the field and it does not yet meet the wish for a flowery grassland. To achieve this, seed will have to be supplied from elsewhere, for example through grass clippings from a species-rich plot.

The chemical analysis show that it is a considerably nutrient-poor area and in any case, poorer than a "normal" farm pasture. The acidity of the soil is low, which was already noted on the basis of the species composition; the soil is on the surface acidified. That is why liming is recommended. The vegetation was also felting, which is unfavourable for a species diverse grassland. A slightly more intensive grazing can prevent this, which will be implemented in 2021.

The grazing period by the chickens was however short and the grazing would have to run longer to be able to actually expect effects. 


\section{$1 \quad$ Inleiding}

\subsection{Aanleiding}

Met Natuur Mee, van initiatiefnemer Sanne Beld, praktiseert, ontwikkelt en promoot een regeneratieve (veerkrachtige) landbouwmethode geïnspireerd door ervaringen in het buitenland (Joel Salatin, Allan Savory etc.). Samen met haar partners en vrijwilligers wil Met natuur Mee een voorloperslocatie ontwikkelen voor veerkrachtige landbouw, inspiratie bieden aan jonge boeren, kennisdelen, onderzoek doen maar bovenal een voedzame oogst bieden die mensen weer met het landschap verbindt.

Kruidenrijke graslanden met bestemming natuur (type 12.02) die op hoge zandgronden liggen (o.a. in Twente), zijn gevoelig geworden voor verdroging, biodiversiteitsverlies en een slechte bodembiologie. Daar komt bij dat er in Overijssel veel Natura 2000 gebieden zijn met bufferzones er omheen die minder interessant zijn voor gangbare boeren (o.a. i.v.m. het nieuwe stikstofbeleid). In deze gebieden liggen of ontstaan meer hectares kruidenrijk grasland, die veerkrachtiger moeten worden om werkelijk te bufferen voor de natuurkern.

Gezien bovenstaande én de mogelijke effecten van klimaatverandering is er genoeg reden om te onderzoeken of de door Met Natuur Mee gebruikte methode bruikbaar is voor de ontwikkeling van een meer veerkrachtig kruidenrijk grasland. Met Natuur Mee verwacht dat wat betreft het beheer van kruidenrijk grasland op droge zandgrond er veel te behalen valt met een landbouwmethode bestaande uit een mobiel en gepland beweidingsbeheer met kippen en koeien. Deze methode moet resulteren in kruidenrijk grasland met een bodem met meer buffercapaciteit (waterhuishouding wordt efficienter), meer organische stof $\left(\mathrm{CO}_{2}\right.$ binding) en betere beschikbaarheid van nutriënten. Dit met behoud of vergroten van de diversiteit van de vegetatie.

In dit onderzoek gaan Wageningse wetenschappers op zoek naar antwoord op de vraag: Wat is het effect van mobiel beweidingsbeheer met koeien en kippen op kruidenrijk grasland op droge zandgrond? Wat doet dit boven en onder de grond qua bodemleven, vochthuishouding en soortenrijkdom van de vegetatie? Dat doen we door de effecten van het beheer op het huidige perceel dat Met Natuur Mee pacht van Staatsbosbeheer in kaart te brengen. Uit dit onderzoek volgen adviezen voor Met Natuur Mee over het gebruik van mobiele beweidingssystemen met kippen en koeien op kruidenrijk grasland op droge zandgrond. Aangezien dit begrazingsbeheer tijd nodig heeft om zich uit te wijzen zal dit wetenschapswinkelonderzoek met name fungeren als het in beeld brengen van de startsituatie met gerichte adviezen voor verbetering van de bodemsituatie.

\subsection{Doel van het onderzoek}

Nabij het Haaksbergerveen ligt het graslandperceel dat momenteel begraasd wordt met koeien (lakenvelders). De begrazing in 2020 ten tijde van het bezoek was extensief met een volwassen koe en drie kalveren (nog niet optimaal voor het beheer, dat kon pas vanaf 2021)(Figuur 1). Deze dieren kregen geregeld een ander deel van het perceel om te begrazen. Dat gebeurde pas als er 15 tot $20 \mathrm{~cm}$ gras stond. Daarnaast vindt er intensieve begrazing plaats door vleeskippen (ongeveer 50 per ren, 150 in totaal) in een ren, die elke dag verplaatst wordt (Figuur 1). De stukken met minder begroeiing worden begraasd door de kippen. Het perceel wordt eenmaal per jaar gemaaid met nabegrazing in 2020. Vanaf 2021 is er een geschikt aantal koeien en gaat dit begrazingsbeheer volgens plan. De kippen worden bijgevoerd (ongeveer $5 \mathrm{~kg}$ per dag per ren zodra ze bijna slachtrijp zijn). De koeien krijgen alleen kruidenrijk gras.

Het perceel grenst aan drie kanten aan een loofbos en aan een kant aan een zandweg met fietspad. Aan de andere kant van de weg liggen landbouwkundige weilanden en een intensieve schapenhouderij. Het deel van het perceel aan de weg kant (zie ook Figuur 2) ligt duidelijk hoger dan 
die aan de bosrand. Er is een duidelijke droog-nat gradiënt aanwezig die grofweg dwars over het perceel loopt. Het terrein is grofweg 3 ha groot. In 2019 is begonnen met de begrazing door de kippen en liepen er drie lakenvelders.

Het doel van de huidige begrazing is om een kruidenrijk grasland te creëren door middel van begrazing met koeien en kippen. Het effect van de begrazing door kippen met een hoge dichtheid maar een korte tijdsduur van een dag is nog onbekend. De begrazing is in 2019 begonnen en er is geen echte nulmeting beschikbaar, dat wil zeggen metingen van voor de start van de huidige begrazing. Daarvoor in de plaats is er een vergelijkbaar perceel geselecteerd in de nabije omgeving.

Het doel van dit onderzoek was om te onderzoeken of de eerste periode van begrazing met kippen al tot effecten op de vegetatie en op de bodem hebben geleid.

Het perceel is eigendom van Staatsbosbeheer en wordt verpacht.
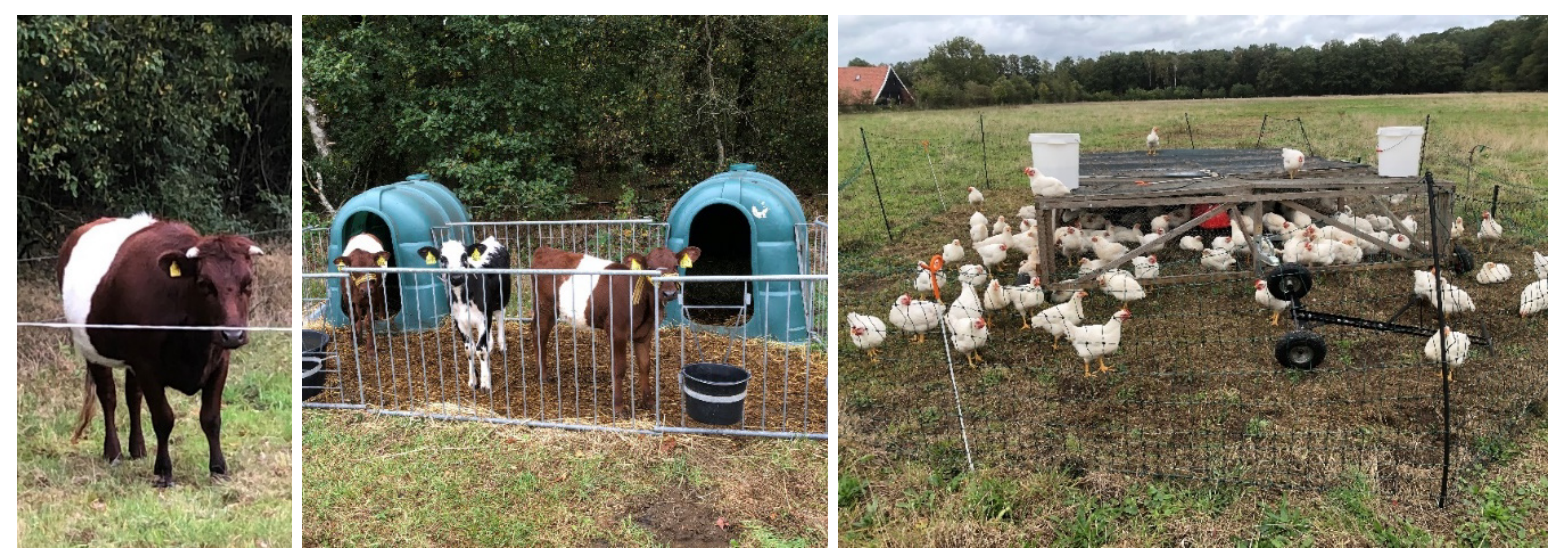

Figuur 1 Begrazing door lakenvelders (links en midden) en kippen in een ren (rechts). 


\section{Materiaal \& Methode}

Het terrein is tweemaal bezocht in het najaar van 2020. Gedurende de twee dagen zijn er vegetatieopnamen gemaakt volgens de Braun-Blanquet methode en twee soorten bodemmonsters genomen. $\mathrm{Er}$ is een monster genomen voor het tellen van regenwormen en andere bodemdieren en een mengmonster om chemische bodemanalyses aan uit te voeren. Deze data zijn verwerkt en geanalyseerd. De stappen worden hieronder beschreven.

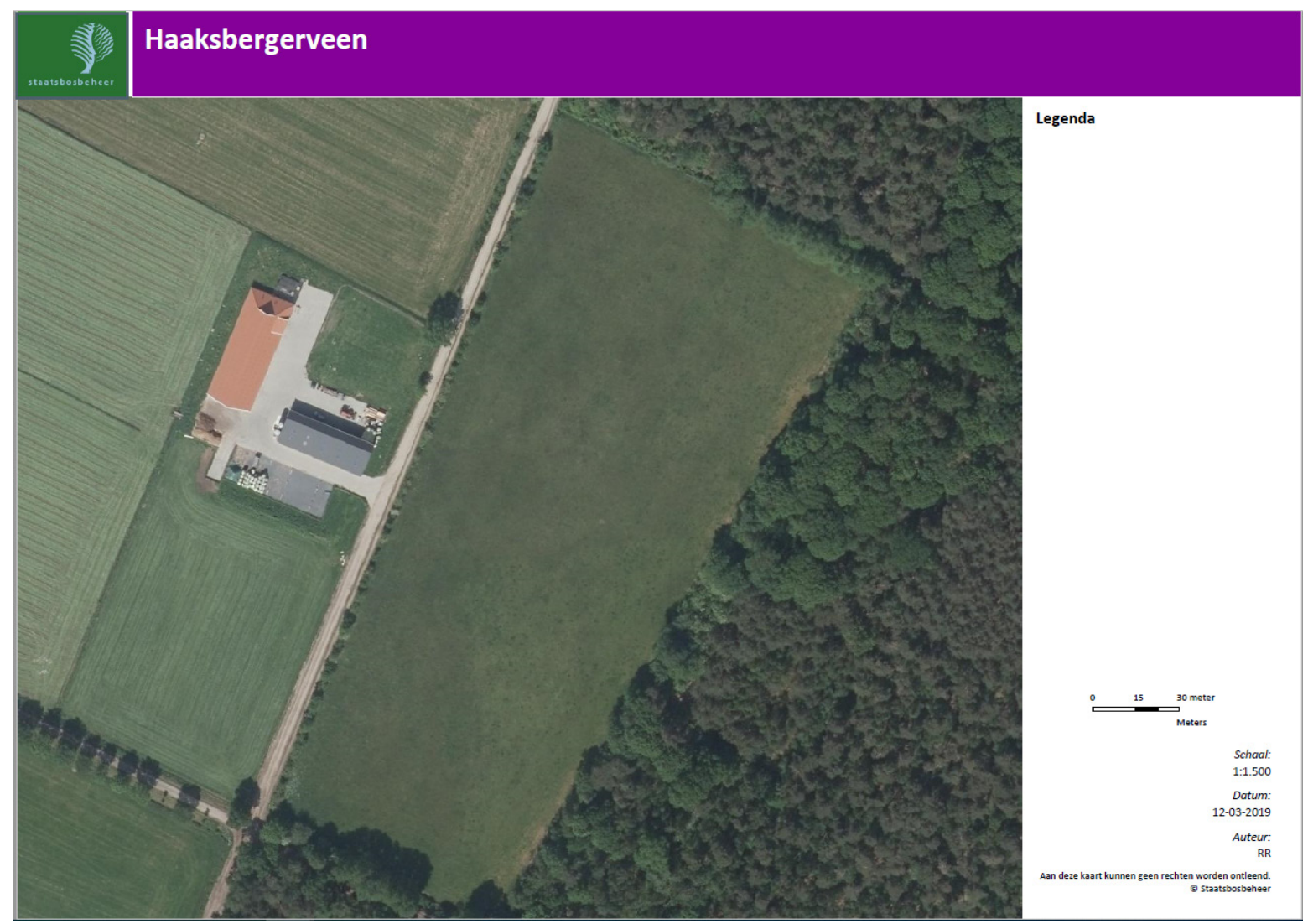

Figuur 2 Begraasde perceel, omzoomd door bos aan drie kanten en de zandweg. Aan de overkant van de weg ligt de schapenboerderij met landbouwkundige graslanden.

\subsection{Opzet vegetatieopnamen en bodemmonstername}

Op basis van de veldsituatie is er een bemonsteringsprotocol opgezet. In het veld duidelijk zichtbaar was de nat-droog gradiënt (grofweg over de breedte van het veld). Op basis hiervan zijn er monsterpunten geselecteerd, dicht bij de weg (droog) en dichtbij de bosrand (nat). Daarnaast was er een duidelijk verschil in biomassa in het veld, die vooral leek samen te hangen met de nat-droog gradiënt. Ook was er een effect van de begrazing van de lakenvelders aanwezig. Sommige stukken waren nauwelijks begraasd, andere intensiever. Ook op basis daarvan zijn er punten geselecteerd. Tot slot was het effect van kippenbegrazing duidelijk zichtbaar in het veld, zowel van de begrazing in 2020 als die in 2019. Voor beide begrazingsperiodes zijn punten geselecteerd, met daarbij een gradiënt voor het aantal dagen geleden dat de kippen hadden gegraasd. Alle vijf de behandelingen zijn in viervoud bemonsterd. De vijf behandelingen zijn droog (extensief begraasd door koeien), droog (extensief begraasd door koeien), nat (intensief begraasd door koeien), begraasd door kippen in 2019 en begraasd door kippen in 2020. Deze behandelingen zijn onderling met elkaar vergeleken. 
Omdat de nulsituatie niet bekend is (van voor het huidige beheer) is er gezocht naar een vergelijkbare situatie in de buurt. Een wat verderop gelegen perceel van Staatsbosbeheer is gebruikt als nulsituatie (Figuur 3). Het perceel wordt ook verpacht en eenmaal per jaar gemaaid met extensieve nabeweiding. Er wordt niet bemest en dit beheer vindt mogelijk al 20 jaar plaats. Het weiland grenst aan twee kanten aan een weg (eenmaal in de lengte en eenmaal in de breedte) en de andere twee kanten aan een loofbos. Mogelijk is er een keer in het verleden een bloemrijk grasland mengsel uitgezaaid. Gezien de staat van dit weiland kan het eerder als een toekomstbeeld worden beschouwd dan als een nulsituatie vanuit een landbouwkundige situatie. Ook in dit perceel is een duidelijk nat droog gradiënt aanwezig. Op basis daarvan zijn er vijf monsterpunten geselecteerd in het natte deel en vijf in het droge deel.

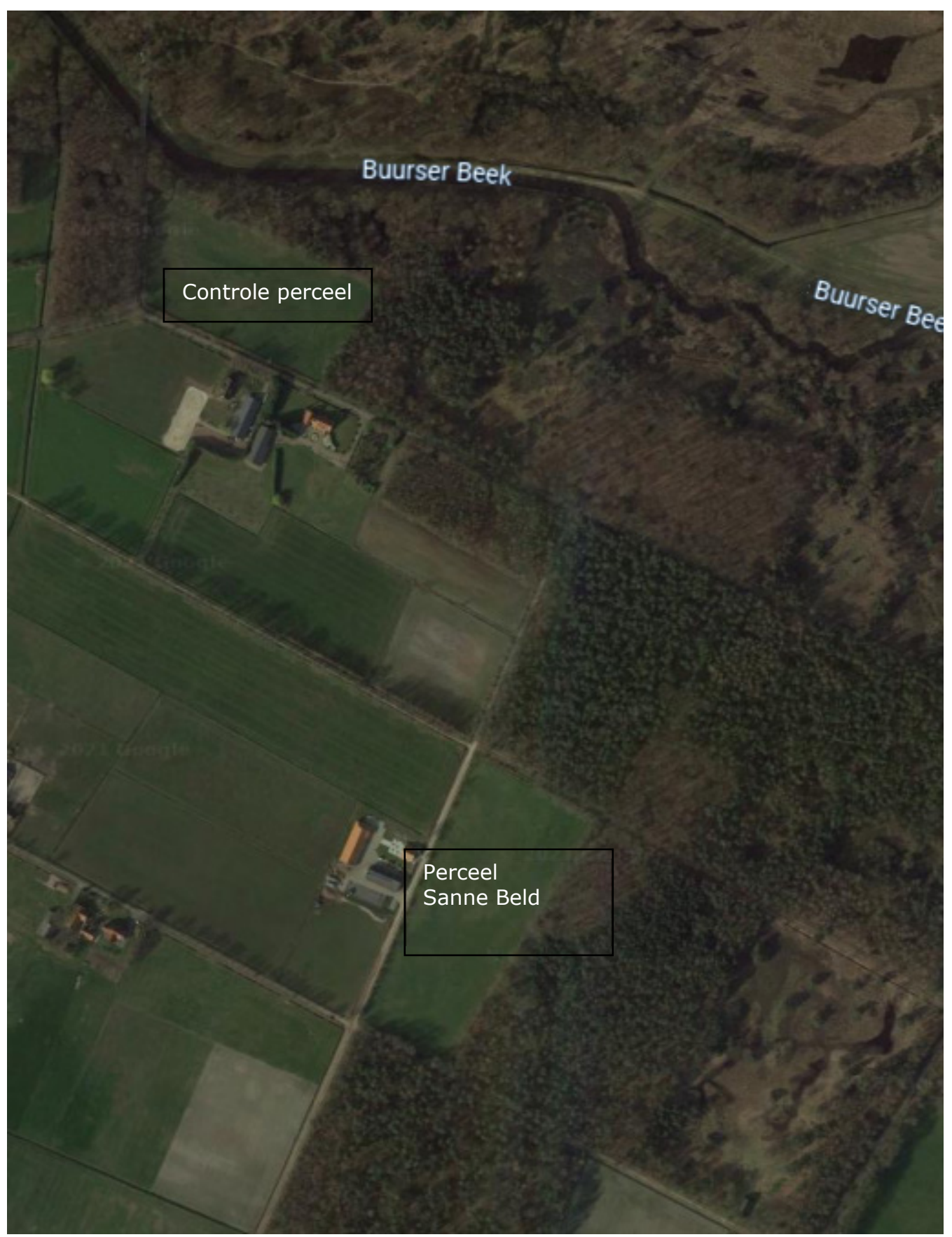

Figuur 3 Ligging van het Perceel met de kippenbegrazing en het controle perceel bij de Buurser Beek, bij Haaksbergen. Bron Google Earth. 
Alle opnamen liggen zover uit elkaar dat zoveel mogelijk pseudoreplicatie (niet onafhankelijke metingen) wordt voorkomen.

De vegetatieopnamen zijn als volgt genummerd:

- Droog: 1-4

- Kip 2019: 5-8

- Kip 2020: 9-12

- Begraasd nat intensief: $13-16$

- Begraasd nat extensief: $17-20$

- Controle droog: 21-25

- Controle nat: $26-30$

Naast de vegetatieopnamen is er ook een totale soortenlijst opgemaakt voor beide weilanden. Waarbij als grens het prikkeldraad is aangehouden. Dat betekent dat randsoorten en dus randeffecten zijn meegenomen.

\subsection{Vegetatieopnamen}

De vegetatieopnamen zijn gemaakt volgens de Braun-Blanquet methode. De opnamen zijn $3 * 3 m$ groot en alle hogere plantensoorten zijn genoteerd en hun bedekking is geschat, naast de totale bedekking van de vegetatie. Mossen zijn niet meegenomen in de vegetatieopnamen. De opnamen zijn allemaal vastgelegd met GPS zodat ze later opnieuw bezocht kunnen worden. De opnamen zijn ingevoerd in Turboveg. Om de verschillen in soortensamenstelling tussen de opnamen weer te geven is een Principale Componenten Analyse (PCA) uitgevoerd m.b.v. het programma Canoco.

\subsection{Bodemmonstername}

Er zijn twee typen bodemmonsters genomen, voor bodemleven analyse en voor chemische analyse.

Voor de analyse van het bodemleven is er één bodemmonster genomen dicht bij het middelpunt van de vegetatieopname. Hiervoor is een bodemgrondboor gebruikt met een diameter van $8 \mathrm{~cm}$ en een diepte van $15 \mathrm{~cm}$. Het monster is in een plastic zak bewaard en na aankomst in Wageningen opgeslagen in een koelcel van $4^{\circ}$ Celsius. Na een en twee weken opslag zijn de monsters gespoeld met water en gezeefd met twee zeven met zeefopening van 6 en $4 \mathrm{~mm}$. De regenwormen en ander macrobodemleven zijn per soortgroep geteld. De regenwormen zijn niet apart geanalyseerd en op naam gebracht.

Voor de chemische bodemanalyse is per vegetatieopname een mengmonster genomen. In de opname zijn met een guts negen steken genomen. De bovenste $10 \mathrm{~cm}$ is genomen voor het verzamelmonster, nadat losse strooisellaag was verwijderd (indien aanwezig). De monsters zijn na thuiskomst bewaard in een koelcel bij $4^{\circ}$ Celsius. Eurofins b.v. te Wageningen heeft de chemische analyses uitgevoerd volgens de bij hen geldende standaardprotocollen. 


\section{Resultaten}

\subsection{Algemene indruk van het perceel}

Bij het veldbezoek viel direct op dat er een tweedeling is in het perceel, een wat hoger en droger gelegen deel dat grenst aan de weg en een wat lager en natter deel richting het bos (foto 1-4). Dit was ook duidelijk zichtbaar in de aanwezig biomassa, het droge deel was spaarzamer begroeid, met deels open plekken, terwijl het nattere deel eruitzag als een landbouwkundig grasland met behoorlijk wat biomassa. Ook de droogte viel direct op, vooral in het droge deel, maar ook het nattere deel was kurkdroog. Dit wordt bevestigd door de bodemanalyses.

Op basis van de aanwezige soorten werd ook ingeschat dat de bodem oppervlakkig verzuurd zou moeten zijn, vooral in het droge deel. Ook deze waarneming wordt bevestigd door de bodemanalyses.

Het effect van de kippenbegrazing was duidelijk zichtbaar in het veld, waarbij zich een prachtige gradiënt had gevormd met bedekking van de vegetatie. Daar waar de kippen net waren geweest was de bedekking minimaal en was er veel door organisch materiaal aanwezig (foto 5-8). Vooral Plantago lanceolata (smalle weegbree) had zich weten te handhaven. Naarmate de begrazing langer geleden was, was er een grotere bedekking van de vegetatie. Het effect van de kippenbegrazing was nog vele weken terug te zien.

Het veld ligt ingeklemd tussen bos en een zandweg met fietspad met daarachter landbouwkundige weilanden met weinig soorten. De weg langs de verharde weg die eindigt bij de ingang van het weiland heeft een vrij brede berm. Omdat de vergroting van de plantensoortenrijkdom in het perceel van buiten zal moeten komen is de ligging niet heel gunstig. Het bos bevat geen gewenste plantensoorten voor graslanden en vormt een barrière voor winddispersie. De weilanden in de omgeving bevatten ook geen gewenste soorten. De bermen zouden wel wat soorten kunnen bevatten, maar dat is niet onderzocht. Langs het bos is een randeffect aanwezig van beschaduwing en soorten die bij een randzone horen en die deels in het weiland komen. Ook langs de wegkant is een randzone aanwezig met meer soorten dan in het weiland zelf. Mede omdat er wat struweel aanwezig is. Een grotere soortenrijkdom is aanwezig in het controle perceel dat verder op ligt (Figuur 3, foto 9-12). Dit perceel is al een tijd in extensief gebruik. 

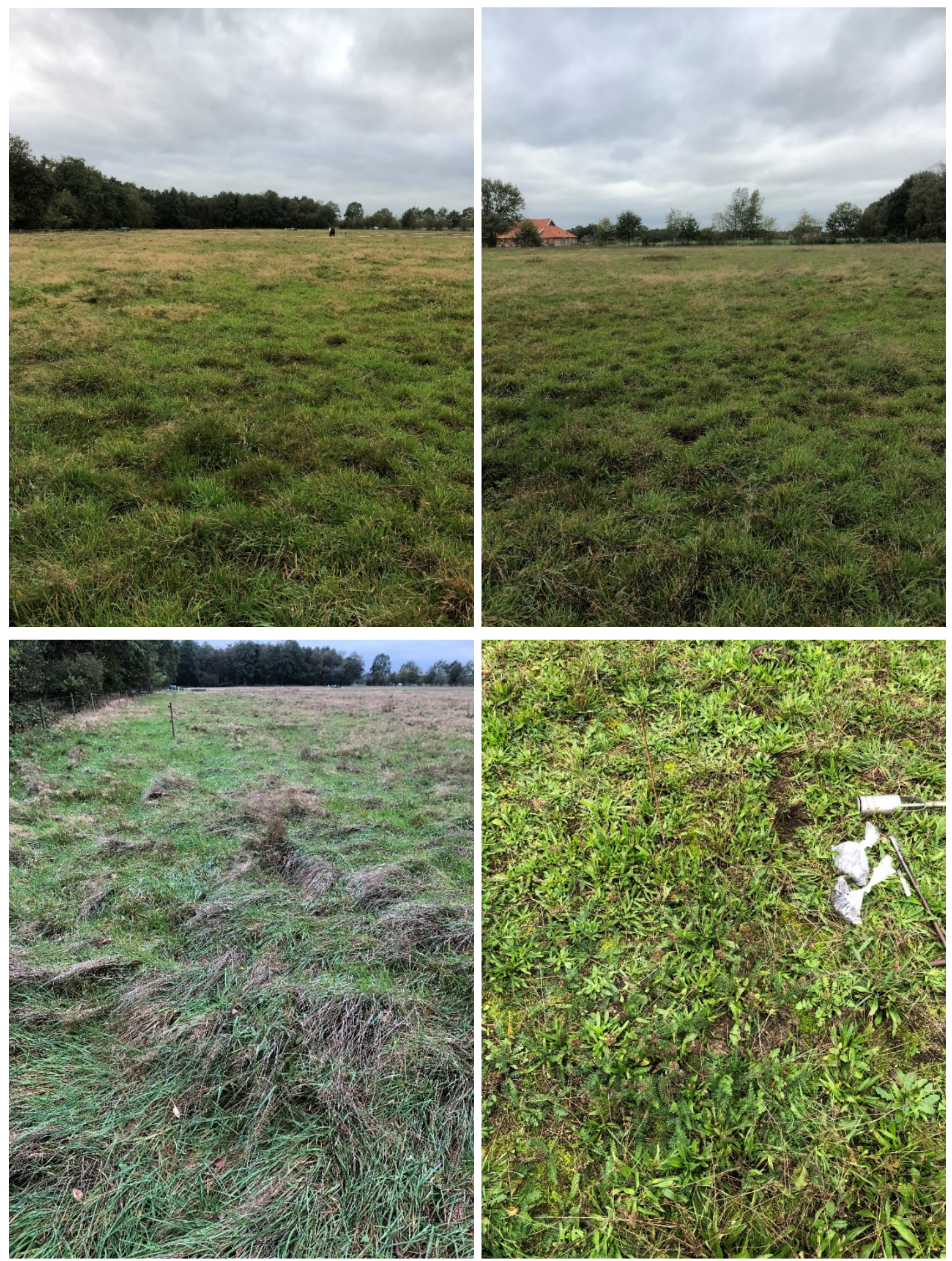

Foto 1-4 Beeld van het weiland begraasd met Lakenvelders en kippen. Met links en rechts boven overzicht, links beneden lang gras in het wat natter deel en rechts vegetatie met bodemmonsters in het wat drogere deel. 

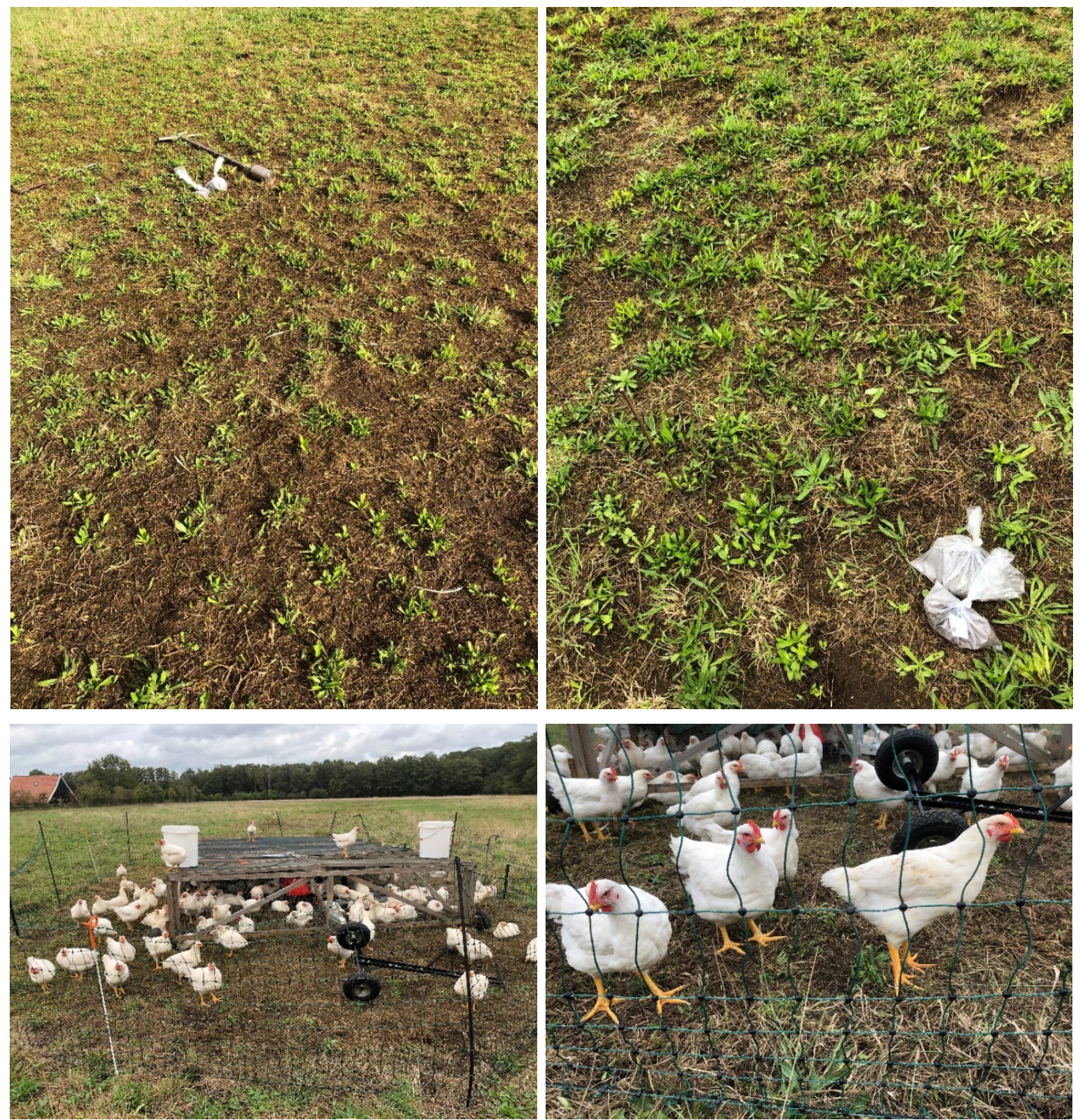

Foto 5-8 Vegetatieopnamen in de recent door kippen begraasde delen (links en rechts boven), met veel open plekken tussen de voornamelijk smalle weegbree en dood plantmateriaal. Links beneden de ren met kippen en rechts beneden het effect van de begrazing op de vegetatie tijdens de begrazing. 

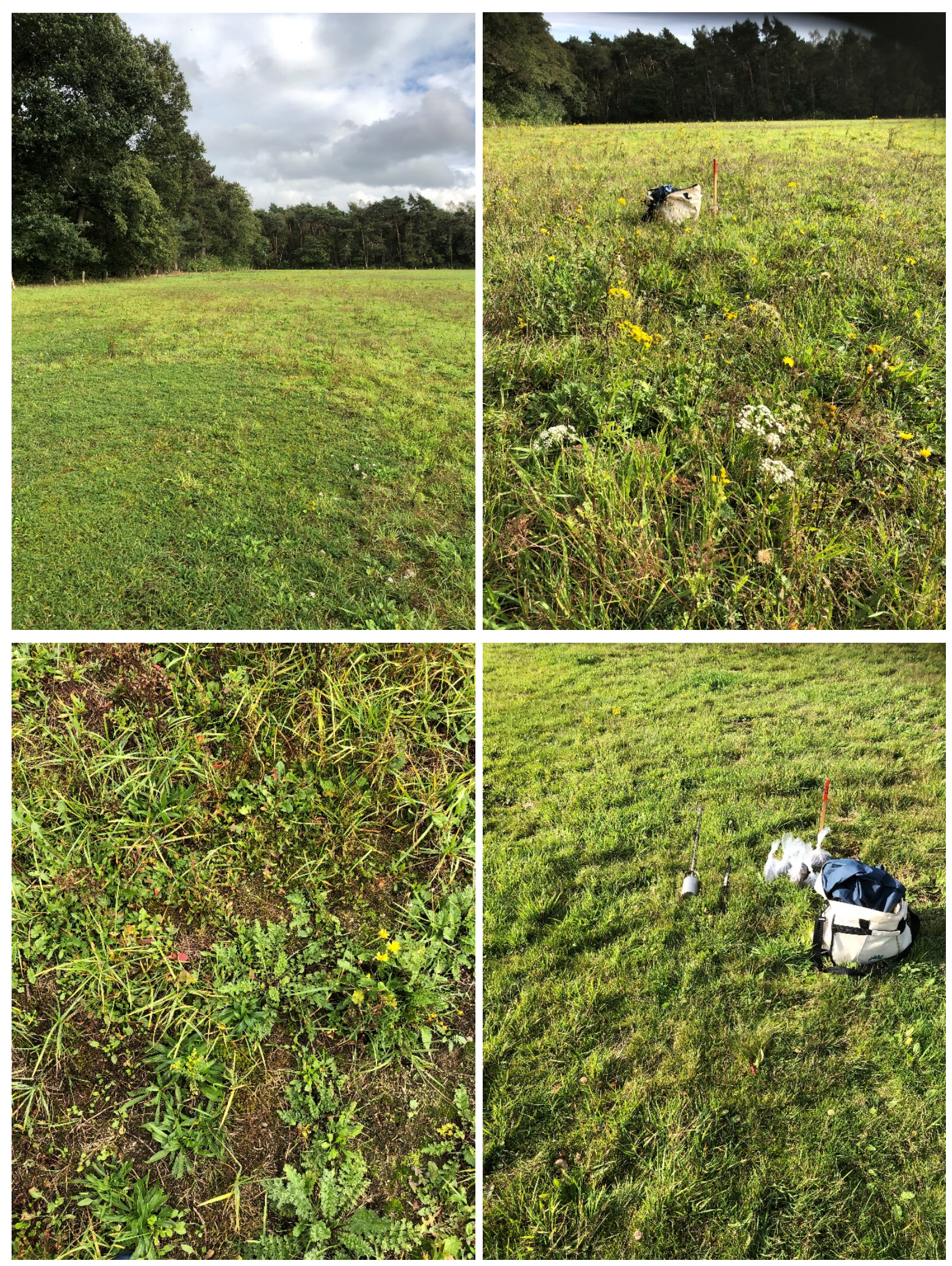

Foto 9-12 Overzicht van het controle perceel (links en rechts boven) en beeld van vegetatieopnamen (links en rechts beneden). 


\subsection{Vegetatieopnamen}

Het gemiddeld aantal soorten per opname per behandeling varieert (Figuur 4). De opnamen in de begrazing met kippen in 2020 geeft de minste soorten en significant minder het droge deel, begrazing met kippen in 2019 en het controle weiland (Tabel 1). Het controle weiland heeft significant meer soorten behalve met het droge deel van het weiland. Verschil tussen het droge deel en het controle weiland is wel dat er in het droge deel alleen algemene soorten voorkomen. In het controle weiland zitten ook een aantal interessantere grasland soorten van het bloemrijk grasland zoals Wilde Bertram, Kleine bevernel, Gewone ereprijs, Tijmereprijs, Avondkoekoeksbloem, Kale jonker en Vijfvingerkruid (Bijlage 2).

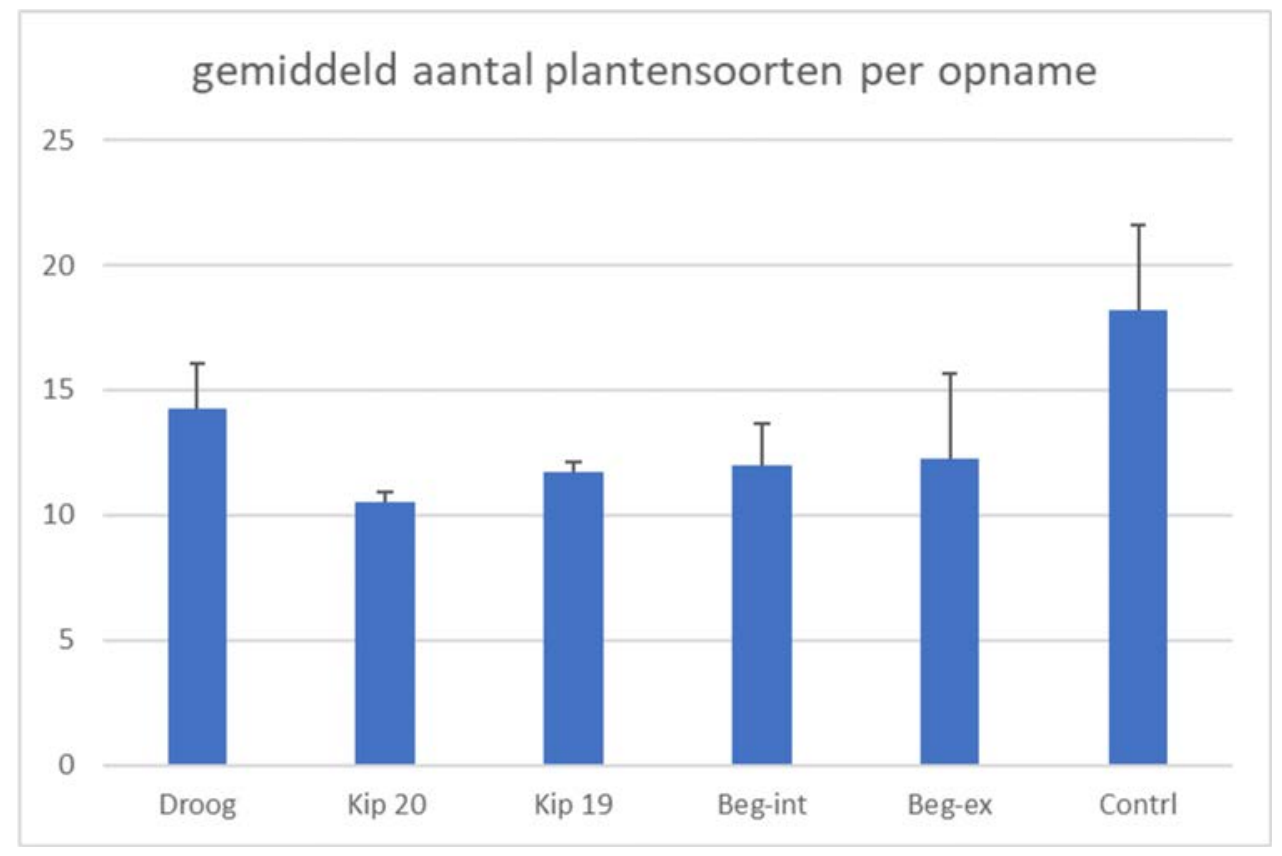

Figuur 4 Gemiddeld aantal plantensoorten per vegetatieopname. Significantie van de verschillen zijn te vinden in Tabel 1.

Tabel 1 Significantie van de verschillen tussen de beheervormen, N.S: niet significant, * significant verschil $(p<0,05)$, $* *$ significant verschil $(p<0,01)$.

\begin{tabular}{llllll}
\hline & kip 20 & kip $\mathbf{1 9}$ & Beg_int & Beg_ext & Controle \\
\hline droog & $*$ & N.S. & N.S. & N.S. & N.S. \\
\hline kip 20 & & $*$ & N.S. & N.S. & $* *$ \\
\hline kip 19 & & N.S. & N.S. & $* *$ \\
\hline Beg_int & & & N.S. & $* *$ \\
\hline Beg_ext & & & & $*$
\end{tabular}




\subsection{Belangrijkste verschillen tussen de vegetatieopnamen}

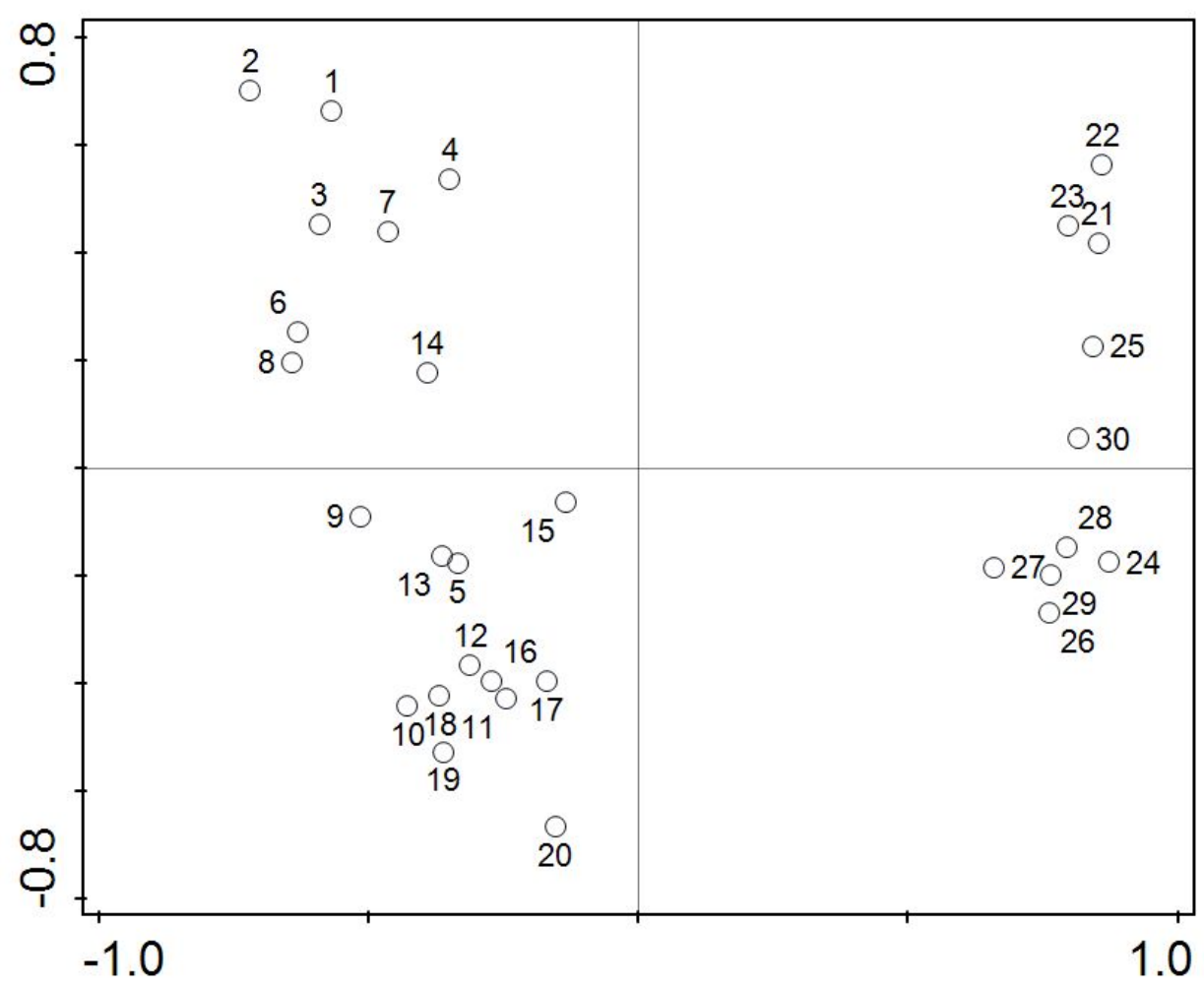

Figuur $5 \quad 1^{\mathrm{e}}$ en $2^{\mathrm{e}}$ as van de PCA op basis van de vegetatieopnamen met behulp van Canoco. Opnamenummers en behandelingen: Droog: 1-4, Kip 2019: 5-8, Kip 2020: 9-12, Begraasd nat intensief: 13-16, Begraasd nat extensief: 17-20, Controle droog: 21-25, Controle nat: $26-30$.

In Figuur 5 staan de opnamen die qua soortensamenstelling op elkaar lijken dicht bij elkaar en opnamen die sterk van elkaar verschillen ver van elkaar op basis van een 'Principal component Analyses' met het statistische programma Canoco. De horizontale as geeft de belangrijkste factor voor de verschillen weer en de verticale as de daarop belangrijkste factor. Als we naar de opnamenummers kijken, zien we dat links alle opnamen uit het proefveld staan en rechts alle opnamen uit het controleperceel. Dat geeft dus aan dat de opnamen uit het controleperceel sterker verschillen van de opnamen uit het proefvak dan de verschillen tussen de behandelingen in het proefvak zelf.

Kijken we naar de verschillen in verticale richting, dan is daar globaal een droog(boven) - nat (onder) gradiënt in te zien, zowel in het proefveld als in de controle. Maar tevens valt op dat in het proefveld de 5 behandelingen niet elk afzonderlijk als groepje duidelijk van elkaar gescheiden liggen, maar geleidelijk in elkaar overgaan. De verschillen tussen de behandelingen (verschillende vormen van begrazing) zijn dus nog vrij klein. 


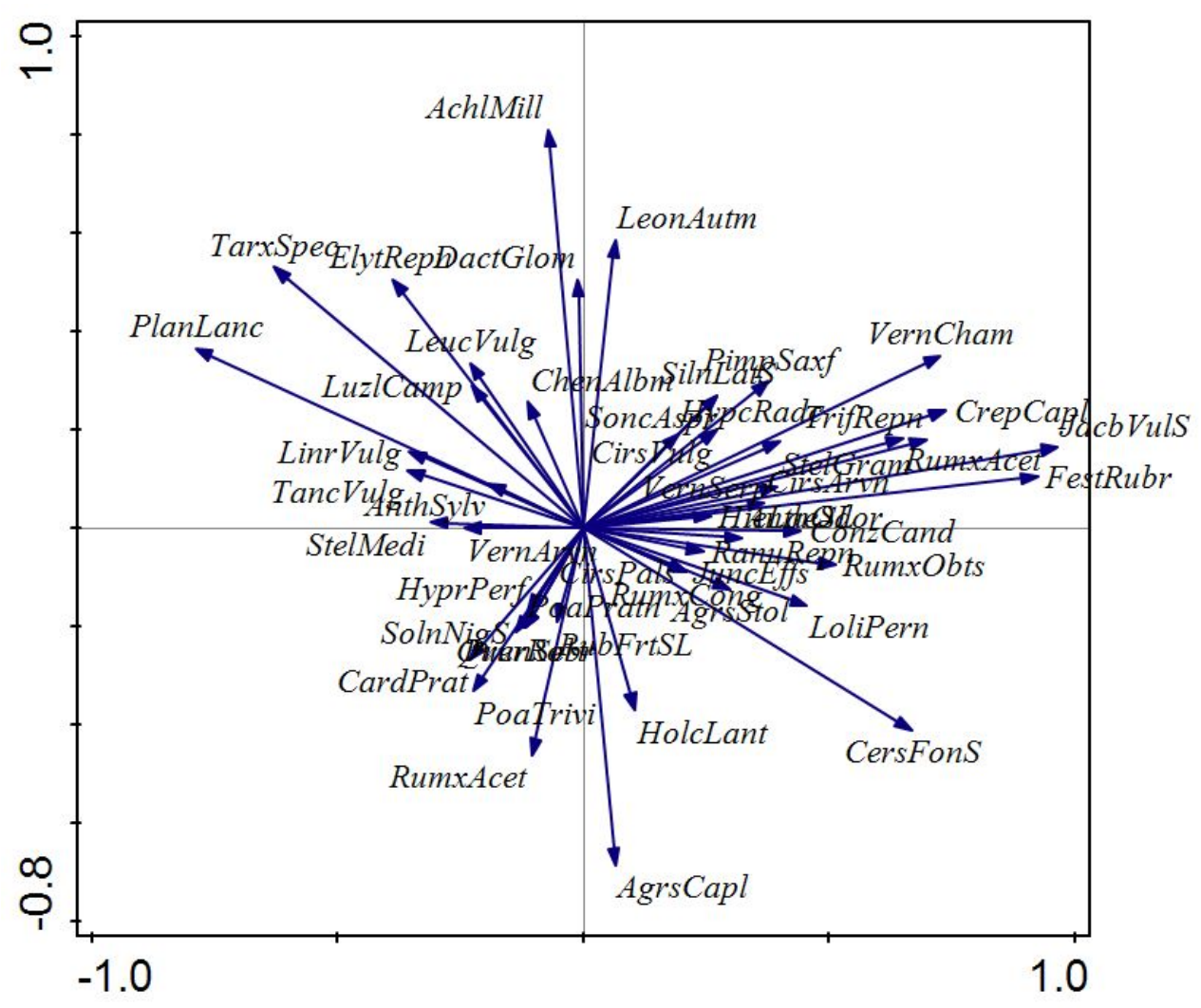

Figuur $61^{\mathrm{e}}$ en $2^{\mathrm{e}}$ as van de PCA op basis van de vegetatieopnamen met behulp van Canoco. Weergegeven zijn de soorten (wetenschappelijke namen afgekort). Langere pijlen geven grotere verschillen aan.

In het soortenplot (Figuur 6) van de PCA zijn de horizontale en verticale as identiek aan die uit het opnamenplot. De soorten die links in het diagram staan (met name die met de langste pijlen) komen meer voor in het proefvak dan in het controleperceel. Dit zijn bijvoorbeeld Smalle weegbree (Plantago Lanceolata), Paardenbloem (Taraxacum spp.) en Kweek (Elytrigia repens). In het controleperceel komen soorten als Gewone ereprijs (Veronica chamaedrys), Klein streepzaad (Crepis capillaris), Jacobskruiskruid (Jacobea vulgaris), Kleine bevernel (Pimpinella saxifraga) en Rood zwenkgras (Festuca rubra) relatief vaker voor. Ook staan links (proefvak) iets meer storingssoorten zoals Zwarte nachtschade (Solanum nigrum), Vlasbekje (Linaria vulgaris) en Vogelmuur (Stellaria media). Je zou hier voorzichtig uit kunnen aflezen dat het grasland in het proefvak nog minder ver in zijn ontwikkeling is. De kippen veroorzaken door hun intensieve graasgedrag ook meer open plekken, vandaar ook wat meer eenjarigen. Het controleperceel lijkt op basis van de soortensamenstelling ook iets schraler. Dit is niet terug te vinden in de gehalten voor voedingsstoffen, die allen vergeleken met een bemest weiland laag zijn.

In de verticale as kunnen we voorzichtig een vochtig (onder) - droog (boven) gradiënt zien. Duizendblad (Achillea millefolium), Veldbies (Luzula campestris) en Margriet (Leucanthemum vulgare) staan vaak op drogere plekken, terwijl pinksterbloem (Cardamine pratensis) en Ruw beemgras (Poa trivialis) op wat vochtiger omstandigheden wijzen. Maar $100 \%$ eenduidig is dit niet, Gewoon struisgras (Agrostis capillaris) heeft de langste pijl naar onder, maar dit is ook zeker een soort die ook op droge zandgrond groeit. Kortom, heel harde conclusies kunnen we hier nog niet uit trekken. 


\subsection{Bodemfauna}

Alle bodemdieren die op de zeven achterbleven zijn geteld per diergroep, regenworm, andere worm en loopkever. Andere diergroepen zijn niet aangetroffen. Het aantal aangetroffen dieren was gering, twee beheervormen (kip2020 en koe extensief) hadden in geen van de vier monsters een dier. Het aantal regenwormen is zeer gering. Het grootste gemiddelde aantal is gevonden in de met kippen in 2019 begraasde deel (Figuur 7). Het aantal is ook significant hoger dan de begrazing met kippen in 2020, extensieve begrazing en de twee controle delen van het controle perceel (Tabel 2). Daarnaast is er nog een significant verschil aanwezig tussen intensieve en extensieve begrazing met koeien. De afzonderlijke waarnemingen zijn te vinden in bijlage 1.

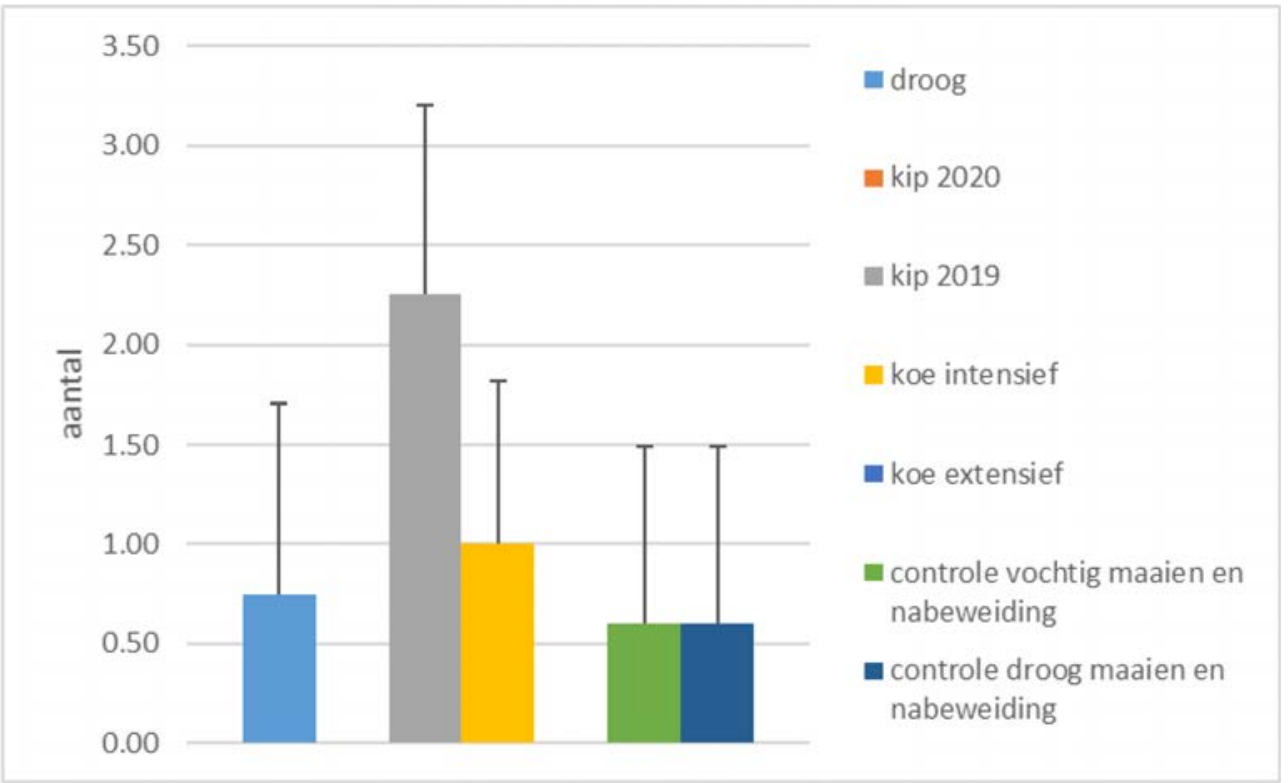

Figuur 7 Gemiddelde aantal bodemdieren (regenwormen, wormen en loopkevers) per beheervorm in het genomen monster, inclusief standard deviatie.

Tabel 2 Significantie van de verschillen tussen de beheervormen, ns: niet significant, * significant verschil $(p<0,05)$

\begin{tabular}{|c|c|c|c|c|c|c|}
\hline & kip 2020 & kip 2019 & koe intensief & $\begin{array}{l}\text { koe } \\
\text { extensief }\end{array}$ & $\begin{array}{l}\text { controle } \\
\text { vochtig } \\
\text { maaien en } \\
\text { nabeweiding }\end{array}$ & $\begin{array}{l}\text { controle } \\
\text { droog } \\
\text { maaien en } \\
\text { nabeweiding }\end{array}$ \\
\hline droog & ns & ns & ns & ns & ns & ns \\
\hline kip 2020 & & * & $*$ & ns & ns & ns \\
\hline kip 2019 & & & ns & $*$ & $*$ & $*$ \\
\hline koe intensief & & & & $*$ & ns & ns \\
\hline koe extensief & & & & & ns & ns \\
\hline $\begin{array}{l}\text { controle vochtig maaien } \\
\text { en nabeweiding }\end{array}$ & & & & & & ns \\
\hline
\end{tabular}




\subsection{Chemische bodemanalyses}

$\mathrm{Er}$ is een hele reeks van bodemchemische en biologische analyses uitgevoerd. De belangrijkste daarvan worden hier getoond. Alle analyses zijn te vinden in bijlage 3.

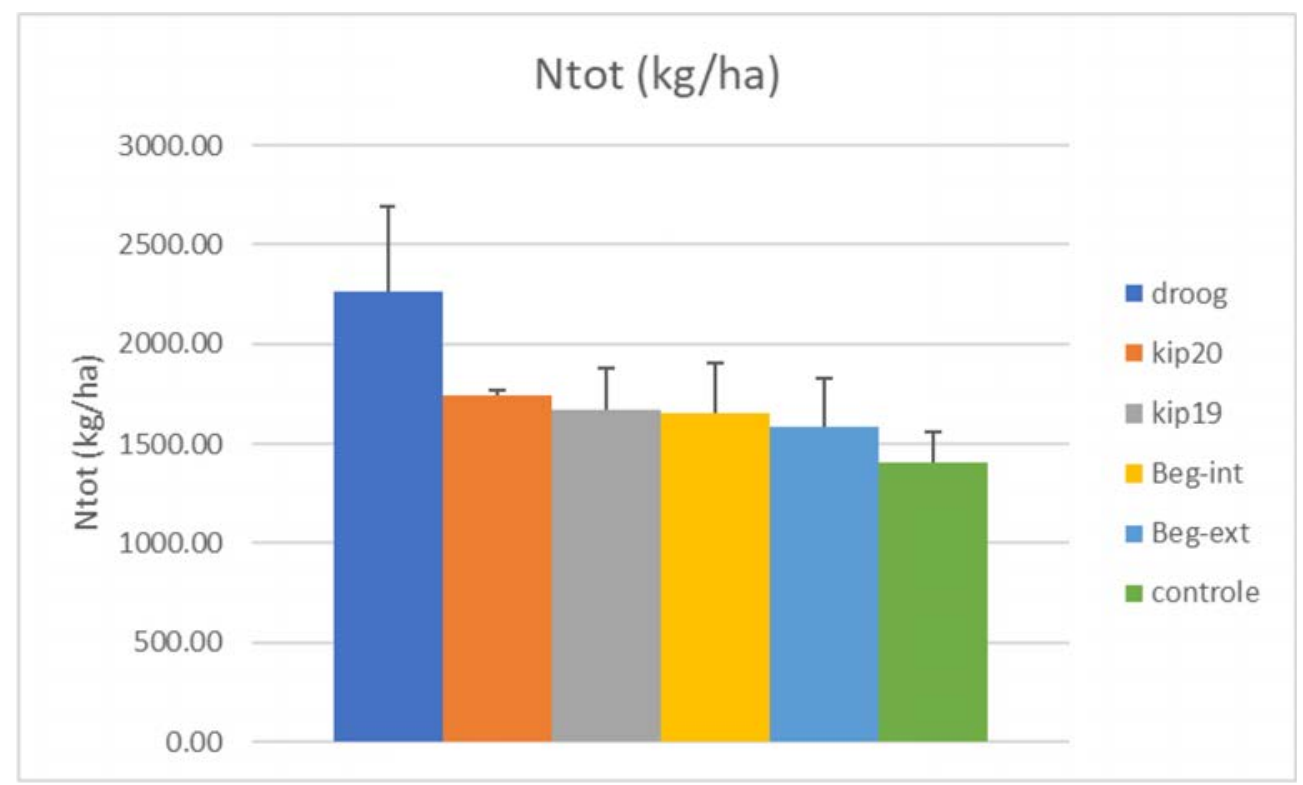

Figuur 8 Totale stikstofgehalte in de bodem per behandeling met standaarddeviatie.

Figuur 8 geeft het totale stikstofgehalte in de bodem. De verschillen zijn niet groot, alleen op het droge gedeelte van het weiland is het stikstofgehalte wat hoger. De gehalten zijn vergeleken met een bemest weiland laag en dat geldt voor alle gehalten in de bodem.

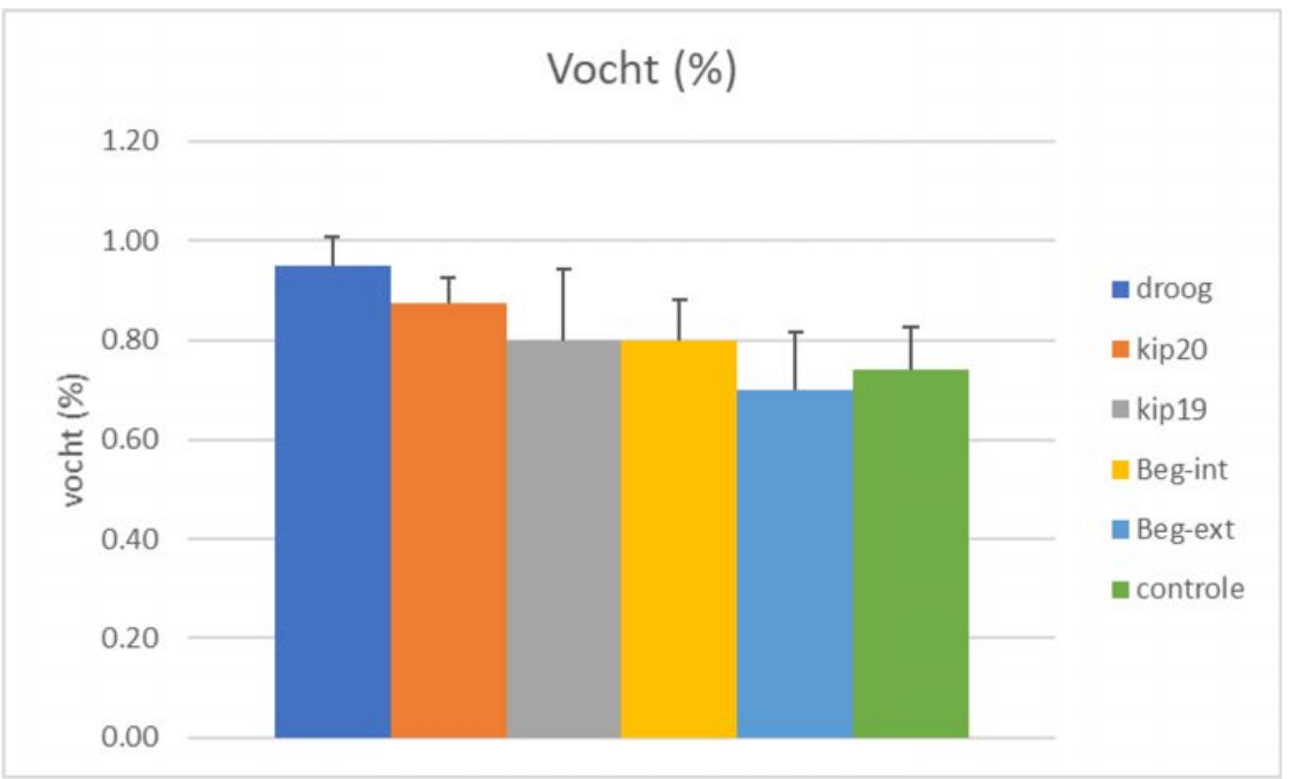

Figuur 9 Vochtgehalte in de bodem per behandeling met standaarddeviatie.

Het vochtgehalte (Figuur 9) in de bodem geeft kleine verschillen te zien. Het Droge deel heeft een iets hoger (!) vochtgehalte dan het natte gedeelte. Echter die verschillen zeggen niets omdat alle gehalten 
zeer laag zijn minder dan 1\%) en overeenkomen met de observaties in het veld dat de bodem na de lange droge zomer (2020) nog steeds zeer droog was.

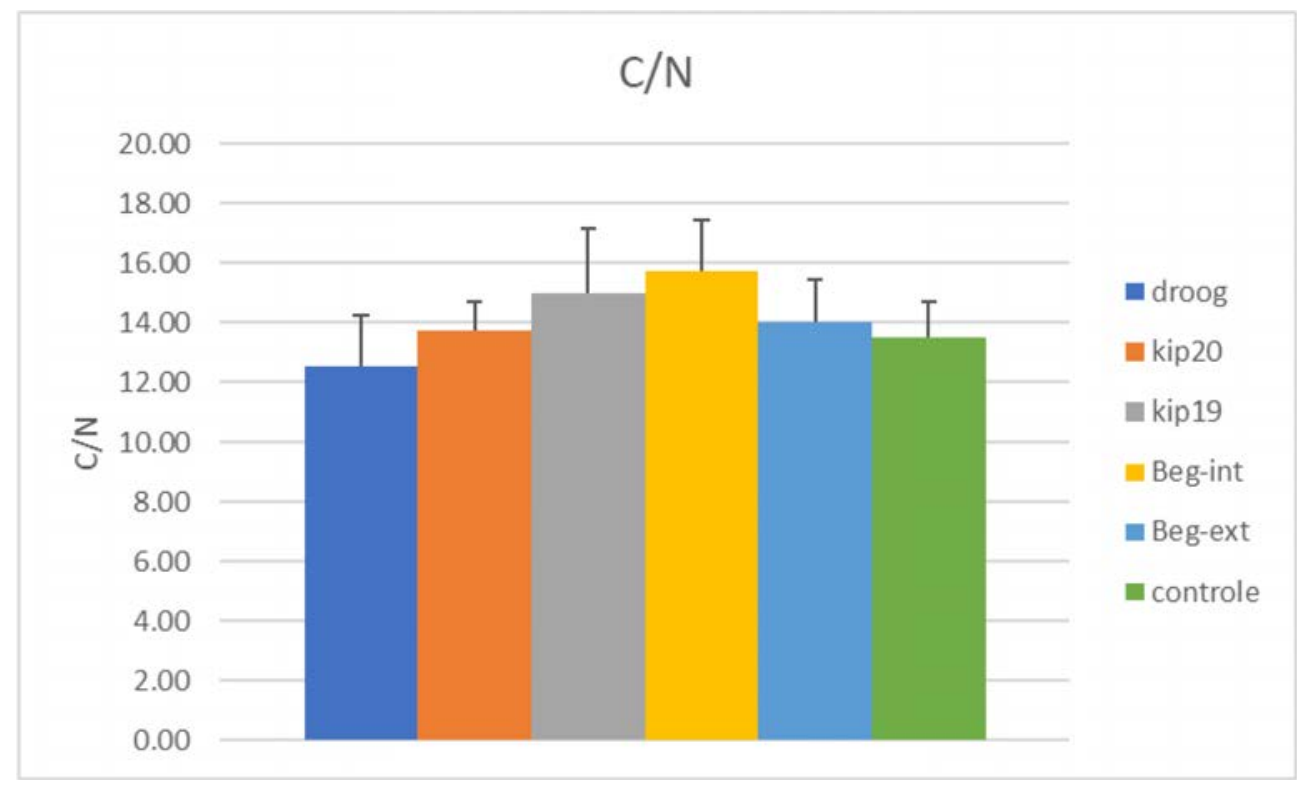

Figuur $10 \mathrm{C} / \mathrm{N}$ in de bodem per behandeling met standaarddeviatie.

Het $\mathrm{C} / \mathrm{N}$ gehalte is het hoogst (dus relatief veel koolstof) voor het deel dat wat intensiever begraasd wordt (Figuur 10). De verhoudingen zijn normaal voor een grasland, al is die wel wat laag voor het droge gedeelte (die een wat hoger stikstofgehalte heeft). De variatie in de herhalingen is zo groot dat de verschillen niet significant zullen zijn.

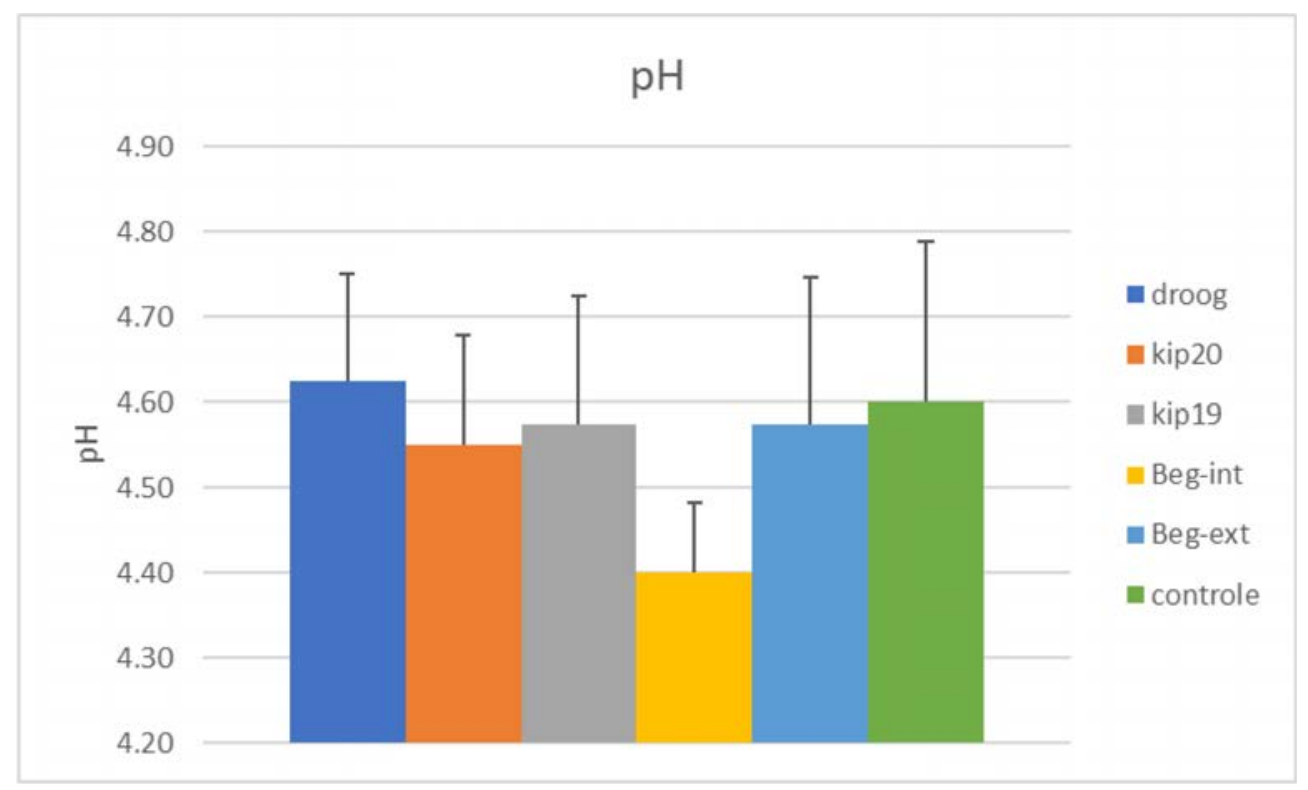

Figuur $11 \mathrm{pH}$ in de bodem per behandeling met standaarddeviatie.

De zuurgraad van de bodem is over de hele linie vrij laag, zeker voor een weiland dat in landbouwkundig gebruik is. Wat ook al in het veld werd geconstateerd wordt hier bevestigd, de bodem is oppervlakkig verzuurd, het meest in het wat intensiever begraasde gedeelte. 


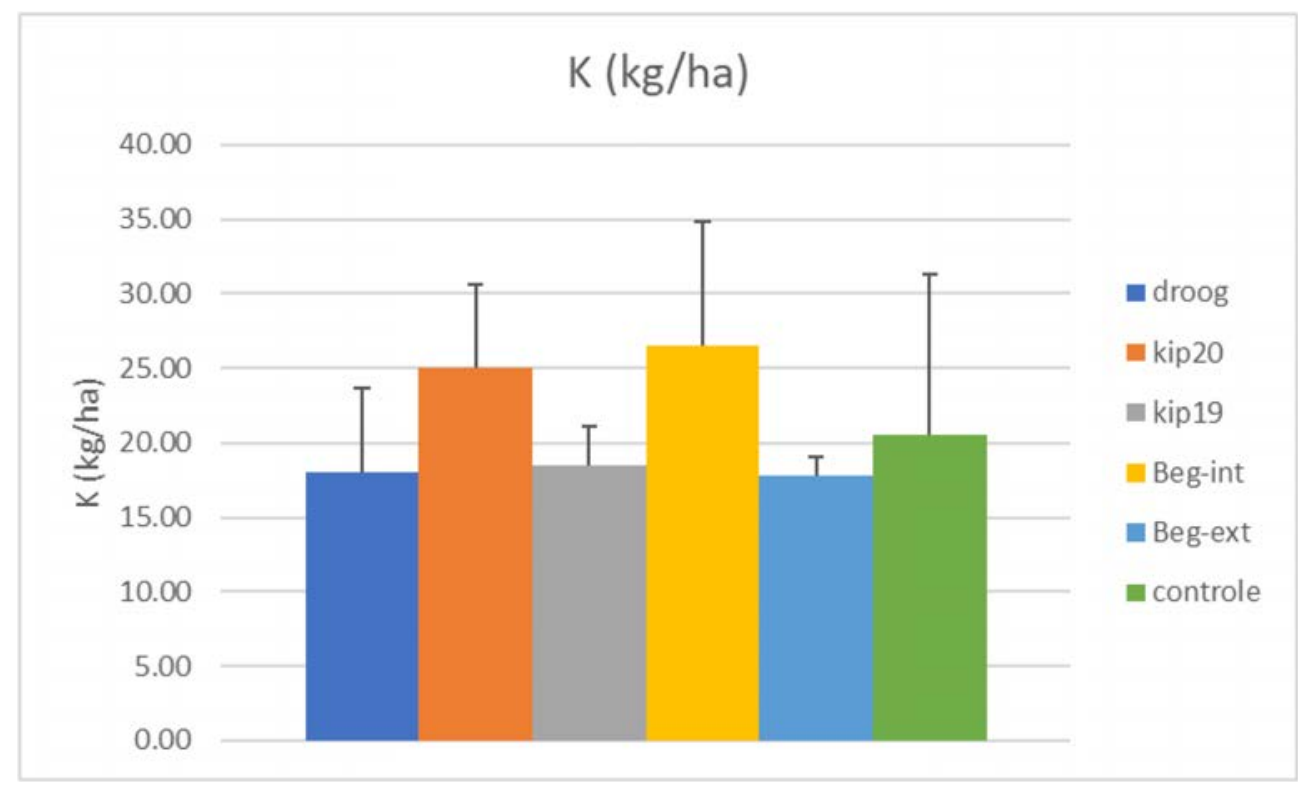

Figuur 12 Kaliumgehalte in de bodem per behandeling met standaarddeviatie.

Het kaliumgehalte vertoond weinig variatie, maar is over de hele linie laag (Figuur 12).

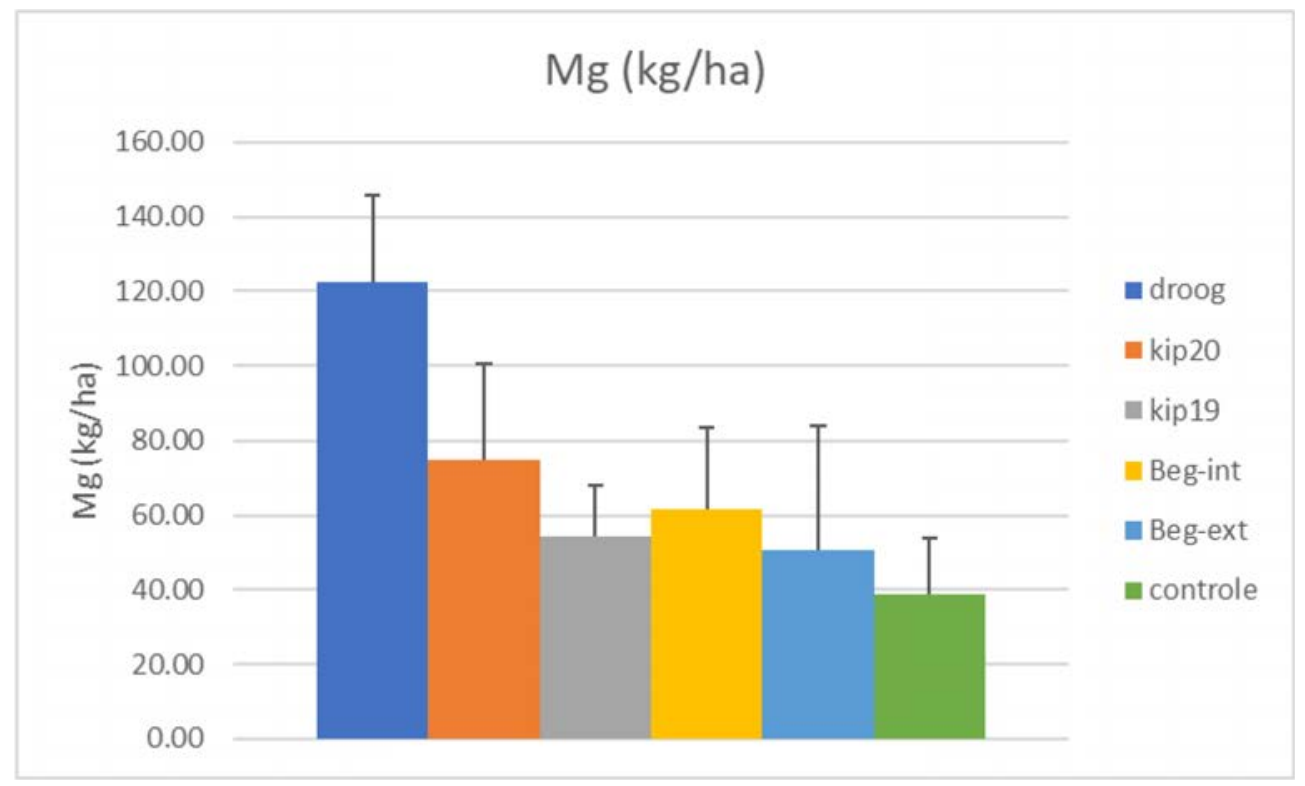

Figuur 13 Magnesiumgehalte in de bodem per behandeling met standaarddeviatie.

Het Magnesiumgehalte in de bodem laat wat meer variatie zien dan het kaliumgehalte, waarbij vooral het gehalte in het droge gedeelte hoger ligt (Figuur 13). In het controle weiland is het magnesiumgehalte het laagste en wezenlijk lager dan het droge gedeelte van het weiland. Ook voor magnesium is het gehalte in de bodem laag. 


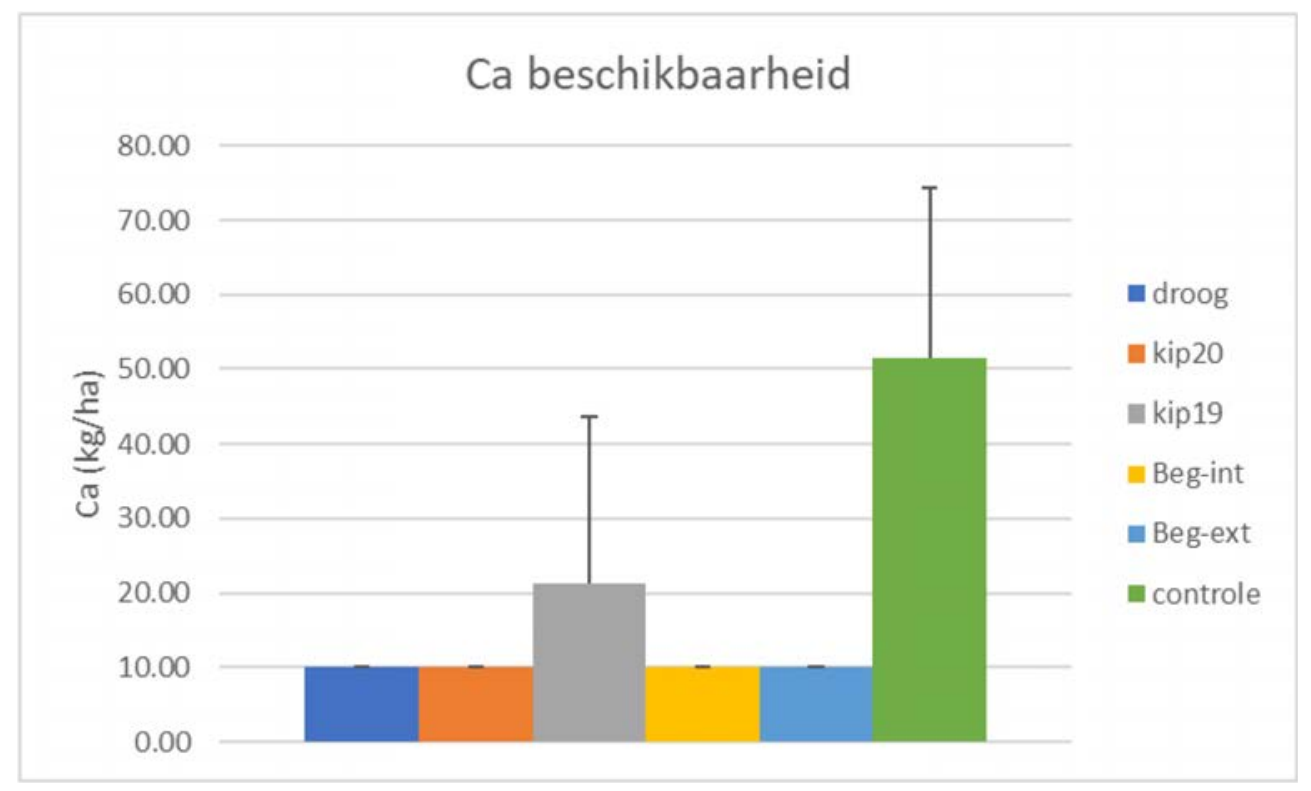

Figuur 14 Calciumgehalte in de bodem per behandeling met standaarddeviatie.

Het calciumgehalte in de bodem is voor het hele weiland laag en iets hoger bij de begrazing met kippen in 2019 (Figuur 14). Het controle experiment heeft een flink hoger gehalte, maar ook hier is het relatief laag, het is ook niet terug te vinden in de $\mathrm{pH}$, die voor beide percelen aan de lage kant is. Voor alle behandelingen behalve kip 19 ligt het gehalte op of onder de detectiegrens.

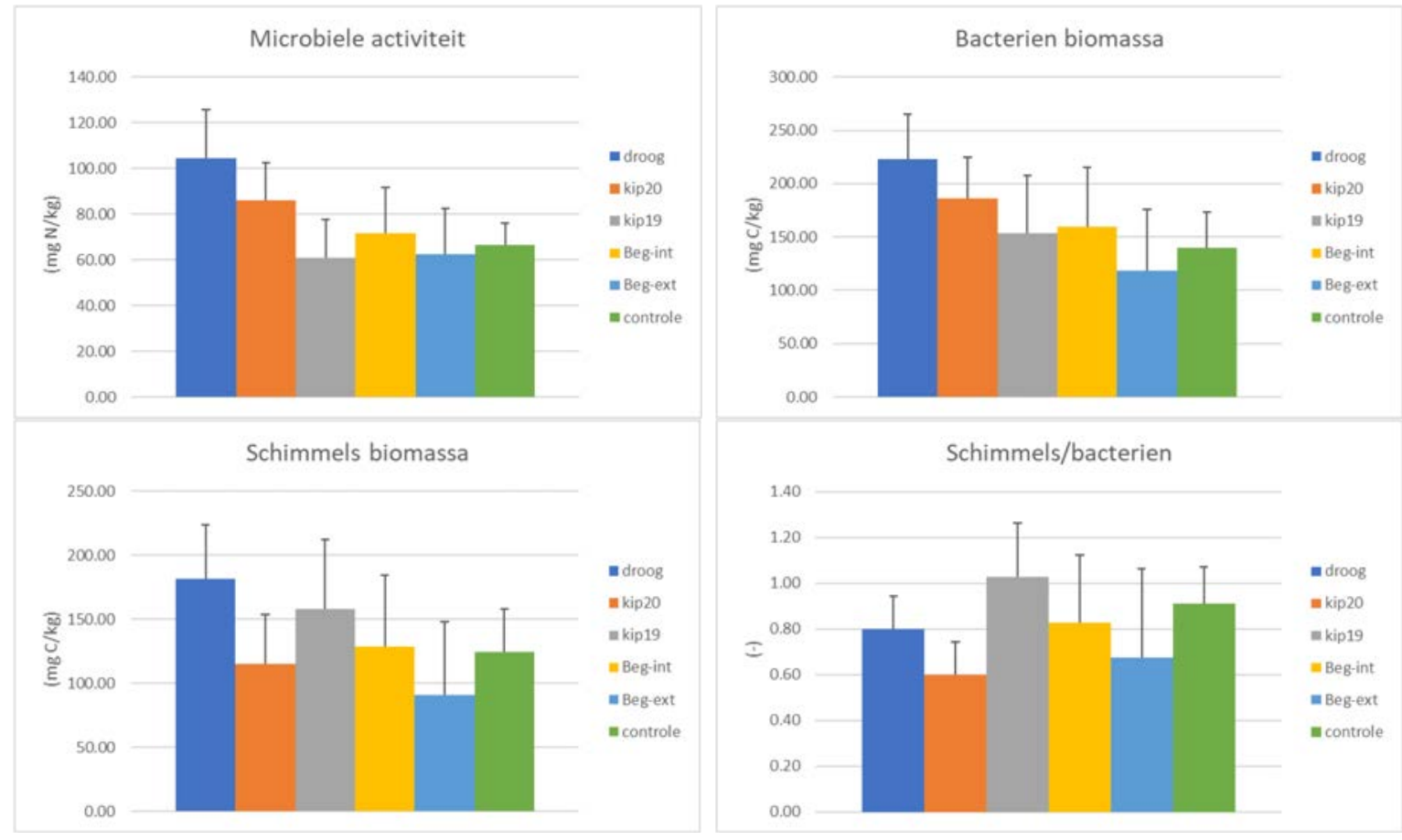

Figuur 15 Microbiële activiteit, biomassa van bacteriën en schimmels en de verhouding schimmels/bacteriën in de bodem met standaarddeviatie.

De microbiële activiteit en de biomassa's vertonen wel variatie, maar de verschillen zijn beperkt, net als de verhouding tussen schimmels en bacteriën (Figuur 15). Ook de waarden voor de controle weide verschillen niet wezenlijk van het onderzochte weiland. Ook de begrazing met de kippen zorgt niet voor andere waarden. 
Over het geheel genomen verschillen de meetwaarden van de verschillende beheervormen, vochtgehalte en begrazingsdruk nauwelijks van elkaar. Ook de verschillen met de controleplot zijn over het algemeen klein of afwezig, met een uitzondering het calciumgehalte in de bodem dat in de controle hoger ligt. Het gehalte basische kationen (kalium magnesium en calcium) is laag, net als de $\mathrm{pH}$. 


\section{Discussie \& Conclusies}

\subsection{Vegetatie}

Het aantal soorten is in het met kippen en koeien begraasde weiland lager dan het controle weiland. Het weiland bevat alleen algemene soorten terwijl het controle weiland ook meer interessante bloemrijkgrasland soorten bevat. De ligging van het weiland is zodanig dat uit de directe omgeving geen verrijking in soortenrijkdom te verwachten valt. Ook uit de zaadbank valt zeer waarschijnlijk niets te verwachten. Dus als het streven is om naar een bloemrijk grasland te gaan dan zou er onderzocht kunnen worden om bijvoorbeeld maaisel uit het controle weiland te halen en dat uit te leggen.

Het begrazen met kippen heeft invloed op zowel de bedekking als de soortenrijkdom, die in het jaar van de begrazing is lager, maar het hersteld zich in het jaar daarop. Het aantal soorten en bedekking in 2019 is niet meer anders dan de andere delen van het weiland.

\subsection{Bodemfauna}

Het aantal gevonden bodemdieren per monster is zeer gering, voor een aanzienlijk deel van de monsters werd geen enkel dier gevonden. Dit wordt met name voor de regenwormen geweten aan de zeer droge omstandigheden (zie ook bodemanalyses). De regenwormen zitten waarschijnlijk veel dieper in rust vanwege de droogte. Dat de kippenbegrazing in 2020, het jaar van de monstername, ervoor zorgt dat er weinig tot geen bodemdieren meer zijn is niet onverwacht. De druk van de kippen is zo groot dat ze waarschijnlijk al het ondiepe bodemleven hebben opgegeten. Het kippengewoel resulteert ook in veel dode biomassa. Dat kan de reden zijn dat de kippenbegrazing in 2019 juist de hoogste aantal bodemdieren laat zien, er is genoeg organisch materiaal om te eten. De verschillen zijn echter gering en het is niet met zekerheid te zeggen dat kippenbegrazing op termijn tot een hogere bodemdierendichtheid leidt. Ook de extensief begraasde plots laten een wat hogere bodemdierendichtheid zien, maar het verschil met de andere beheertypen is meestal niet significant. Langer onderzoek is nodig om dit verder uit te zoeken. Een belangrijke vraag is of het effect van kippenbegrazing zich doorzet en of de in 2019 begraasde delen blijvend een hogere bodemlevendichtheid houden.

\subsection{Chemie}

De bodemanalyses laten zien dat er weinig effecten zijn van de verschillende begrazingsvormen en druk in het onderzochte weiland. Ook de nat droog gradiënt laat geen wezenlijke verschillen zien. Ook in vergelijking met het controle weiland zijn de verschillen gering of afwezig, met een uitzondering, het calciumgehalte in de bodem, dat hoger is in het controle weiland. Wel komt naar voren dat de $\mathrm{pH}$ relatief laag is en dat het gehalte basische kationen relatief laag is. Dit werd voor het droge gedeelte ook al visueel geconstateerd in het veld. De bodem is oppervlakkig verzuurd en een bekalking zou op zijn plaats zijn, dit zou ook het aantal soorten dat voor kan komen kunnen verhogen. Of ze ook daadwerkelijk gaan voorkomen hangt van andere zaken af, zoals beheer en bereikbaarheid van het weiland voor zaden.

Dat de verschillen gering zijn kan komen omdat het perceel pas in zijn tweede jaar is van de huidige begrazing. Dat is relatief kort en dat er nu nog geen verschillen worden gevonden in bodemchemie wil niet zeggen dat die in de toekomst niet kan ontstaan. 


\subsection{Eindconclusies}

De uitgangssituatie is met dit onderzoek min of meer vastgelegd. Om de ontwikkeling echt goed te kunnen volgen en het effect van deze mobiele begrazing met kippen en koeien te meten is een langere periode nodig, het liefst minimaal 10 jaar. Een echte nulmeting is het niet, omdat de begrazing met de kippen al was begonnen, echter een groot deel van het weiland was nog niet met kippen begraasd en kan als zodanig nog wel als blanco worden beschouwd.

Het effect van de kippenbegrazing is nu nog beperkt, hoewel in het veld visueel wel heel duidelijk, met een lage bedekking en een lager soortenaantal in het jaar van de begrazing, maar het herstelt zich snel. In het jaar erop (de begrazing in 2019) heeft de vegetatie zich al hersteld (open plekken zijn weer dicht gegroeid), zonder dat het soortenrijker is geworden. Bodemchemisch zijn er echter geen wezenlijke verschillen. Algemeen valt op dat de zuurgraad en het kalkgehalte van het weiland laag is, het is oppervlakkig verzuurd. Bekalking zou hier een oplossing kunnen bieden.

De plantensoortenrijkdom, zeker wat betreft bloemrijk grasland soorten, is laag en er valt zonder ingrijpen ook niet direct een verbetering te verwachten. De soortenrijkdom zou kunnen worden verhoogd door het inbrengen van zaden uit hooi van een soortenrijk weiland, bijvoorbeeld het controle weiland. Verder is de begrazing is zijn totaliteit nog vrij extensief, hier komt echter vanaf 2021 verandering in. Door de extensieve begrazing is in het nattere en wat productievere gedeelte sprake van enige vervilting. Het advies is om periodiek het perceel intensiever te begrazen, zodat voldoende open plekken ontstaan waar nieuwe soorten in zouden kunnen kiemen. 


\section{$5 \quad$ Toekomstvisie}

De inventarisatie die hier is beschreven is gebaseerd op de situatie zoals die was in 2020. Vanaf 2021 worden de vleeskippen vervangen door mobiel gehouden leghennen omdat zij naar verwachting een positiever effect hebben op de bodem. Zoals aangegeven zullen ook de koeien vanaf 2021 verplaatst worden waardoor de mobiele begrazing beter tot uiting komt.

De botanische diversiteit van het perceel is nu nog laag en er zal zaad, bijvoorbeeld door het inbrengen van maaisel, moeten worden ingebracht. Dan kan zich een bloemrijker weiland zich ontwikkelen, waarbij de soortensamenstelling op het hoger deel wat zal afwijken van het wat lagere en nattere deel bij de bosrand. De ontwikkeltijd zal waarschijnlijk wel zo'n tien jaar vergen.

Om de oppervlakkige verzuring tegen te gaan zou er bekalkt moeten worden, in ieder geval voor het inbrengen van het zaad. Meer graslandsoorten krijgen dan een kans en de bloemrijkdom zal toenemen. Daarnaast zou het veld wat intensiever begraasd moeten worden om vervilting tegen te gaan, maar dit zit in de planning. Het kan nodig blijken af en toe wat ruw stalmest te gebruiken om het weiland niet te schraal te maken waardoor er op termijn te weinig voedsel is voor de koeien. Ruwe stalmest is ook goed voor het bodemleven, dat verbetering lijkt te behoeven, hoewel dat nu lastig was vast te stellen door de grote droogte. Een rijker bodemleven is ook gunstig voor de kippen.

Het is nu nog niet bekend hoe de kippenhouderij met een ren op langere termijn de biodiversiteit zou gaan beïnvloeden. De eerste resultaten lijken niet ongunstig, de vegetatie hersteld zich vrij snel en een jaar na begrazing is er een gesloten vegetatie aanwezig. De kippen creëren wel mogelijkheden voor soorten om zich te vestigen en er zijn ook wel wat kiemplanten gezien, maar bij gebrek aan een hogere soortendiversiteit in de omgeving zijn dat allen de aanwezige soorten. Met uitleggen van soortenrijk maaisel na de kippenbegrazing zou wel eens heel snel een veel diversere vegetatie kunnen ontstaan.

Nu de begrazing waarschijnlijk anders wordt zal het effect daarvan ook anders zijn. Het krapwerk van de kippen zou tot open plekjes kunnen leiden waar nieuwe soorten zich zouden kunnen vestigen. Of dit lukt zal mede afhangen van de graasdichtheid van de koeien. Als die te extensief is zal de vestiging van nieuwe soorten moeilijker worden. Met het nieuwe voorgenomen beheer zou dit probleem opgelost kunnen worden. 


\section{Bijlage 1 Waarnemingen van bodemdieren per monster}

De nummering correspondeert met andere bodemmonsters en vegetatieopnamen. Het gewicht is het versgewicht is het gewicht van het monster. Er is niet gecorrigeerd voor het verschil in gewicht.

\begin{tabular}{|c|c|c|c|c|c|c|c|c|}
\hline $\mathbf{n r}$ & behandeling & $\begin{array}{l}\text { gewicht } \\
\text { (FW in g) }\end{array}$ & $\begin{array}{l}\text { Regen } \\
\text { wormen }\end{array}$ & $\begin{array}{l}\text { Andere } \\
\text { wormen }\end{array}$ & $\begin{array}{l}\text { Loop } \\
\text { kevers }\end{array}$ & & totaal & opmerking \\
\hline 1 & droog & 871,73 & & 0 & 1 & 0 & 1 & oranje worm \\
\hline 2 & droog & 793,52 & & 1 & 0 & 1 & 2 & juveniele regenworm \\
\hline 3 & droog & 806,05 & & 0 & 0 & 0 & 0 & \\
\hline 4 & droog & 887,91 & & 0 & 0 & 0 & 0 & \\
\hline 5 & kip 2020 & 797,32 & & 0 & 0 & 0 & 0 & \\
\hline 6 & kip 2020 & 759,58 & & 0 & 0 & 0 & 0 & \\
\hline 7 & kip 2020 & 772,16 & & 0 & 0 & 0 & 0 & \\
\hline 8 & kip 2020 & 856,51 & & 0 & 0 & 0 & 0 & \\
\hline 9 & kip 2019 & 759,58 & & 2 & 1 & 0 & 3 & $\begin{array}{l}\text { juveniele regenwormen en een } \\
\text { wit wormpje }\end{array}$ \\
\hline 10 & kip 2019 & 772,16 & & 0 & 1 & 0 & 1 & wit wormpje \\
\hline 11 & kip 2019 & 879,17 & & 0 & 1 & 1 & 2 & $\begin{array}{l}\text { wit wormpje en dode wrschlk } \\
\text { loopkever }\end{array}$ \\
\hline 12 & kip 2019 & 816,07 & & 1 & 1 & 1 & 3 & $\begin{array}{l}\text { stukje worm, rest mist, wit } \\
\text { wormpje }\end{array}$ \\
\hline 13 & koe intensief & 742,69 & & 1 & 0 & 0 & 1 & juveniele regenworm \\
\hline 14 & koe intensief & 787,55 & & 0 & 0 & 0 & 0 & \\
\hline 15 & koe intensief & 872,94 & & 0 & 0 & 1 & 1 & \\
\hline 16 & koe intensief & 711,63 & & 1 & 1 & 0 & 2 & $\begin{array}{l}\text { juveniel regenworm en } \\
\text { steekworm (oranje) }\end{array}$ \\
\hline 17 & koe extensief & 742,59 & & 0 & 0 & 0 & 0 & \\
\hline 18 & koe extensief & 774,49 & & 0 & 0 & 0 & 0 & \\
\hline 19 & koe extensief & 730,66 & & 0 & 0 & 0 & 0 & \\
\hline 20 & koe extensief & 758,82 & & 0 & 0 & 0 & 0 & \\
\hline 21 & $\begin{array}{l}\text { controle } \\
\text { vochtig maaien } \\
\text { en nabeweiding }\end{array}$ & 646,07 & & 0 & 0 & 0 & 0 & \\
\hline 22 & $\begin{array}{l}\text { controle } \\
\text { vochtig maaien } \\
\text { en nabeweiding }\end{array}$ & 603,61 & & 0 & 0 & 0 & 0 & \\
\hline 23 & $\begin{array}{l}\text { controle } \\
\text { vochtig maaien } \\
\text { en nabeweiding }\end{array}$ & 761,82 & & 0 & 0 & 2 & 2 & $\begin{array}{l}\text { hele jonge, van de grote } \\
\text { loopkever }\end{array}$ \\
\hline 24 & $\begin{array}{l}\text { controle } \\
\text { vochtig maaien } \\
\text { en nabeweiding }\end{array}$ & 812,99 & & 1 & 0 & 0 & 1 & juveniele regenworm \\
\hline 25 & $\begin{array}{l}\text { controle } \\
\text { vochtig maaien } \\
\text { en nabeweiding }\end{array}$ & 799,02 & & 0 & 0 & 0 & 0 & \\
\hline 26 & $\begin{array}{l}\text { controle droog } \\
\text { maaien en } \\
\text { nabeweiding }\end{array}$ & 546,42 & & 0 & 0 & 0 & 0 & \\
\hline 27 & $\begin{array}{l}\text { controle droog } \\
\text { maaien en } \\
\text { nabeweiding }\end{array}$ & 869,94 & & 0 & 1 & 0 & 1 & oranje worm \\
\hline 28 & $\begin{array}{l}\text { controle droog } \\
\text { maaien en } \\
\text { nabeweiding }\end{array}$ & 769,79 & & 0 & 0 & 0 & 0 & \\
\hline 29 & $\begin{array}{l}\text { controle droog } \\
\text { maaien en } \\
\text { nabeweiding }\end{array}$ & 788,11 & & 1 & 1 & 0 & 2 & $\begin{array}{l}\text { juveniele regenworm en een witte } \\
\text { worm }\end{array}$ \\
\hline 30 & $\begin{array}{l}\text { controle droog } \\
\text { maaien en } \\
\text { nabeweiding }\end{array}$ & 774,57 & & 0 & 0 & 0 & 0 & \\
\hline
\end{tabular}




\section{Bijlage 2 Vegetatieopnamen}

De opnamen zijn goed leesbaar bij 200* vergroting, maar ook beschikbaar als Excel file (uitdraai uit Turboveg).

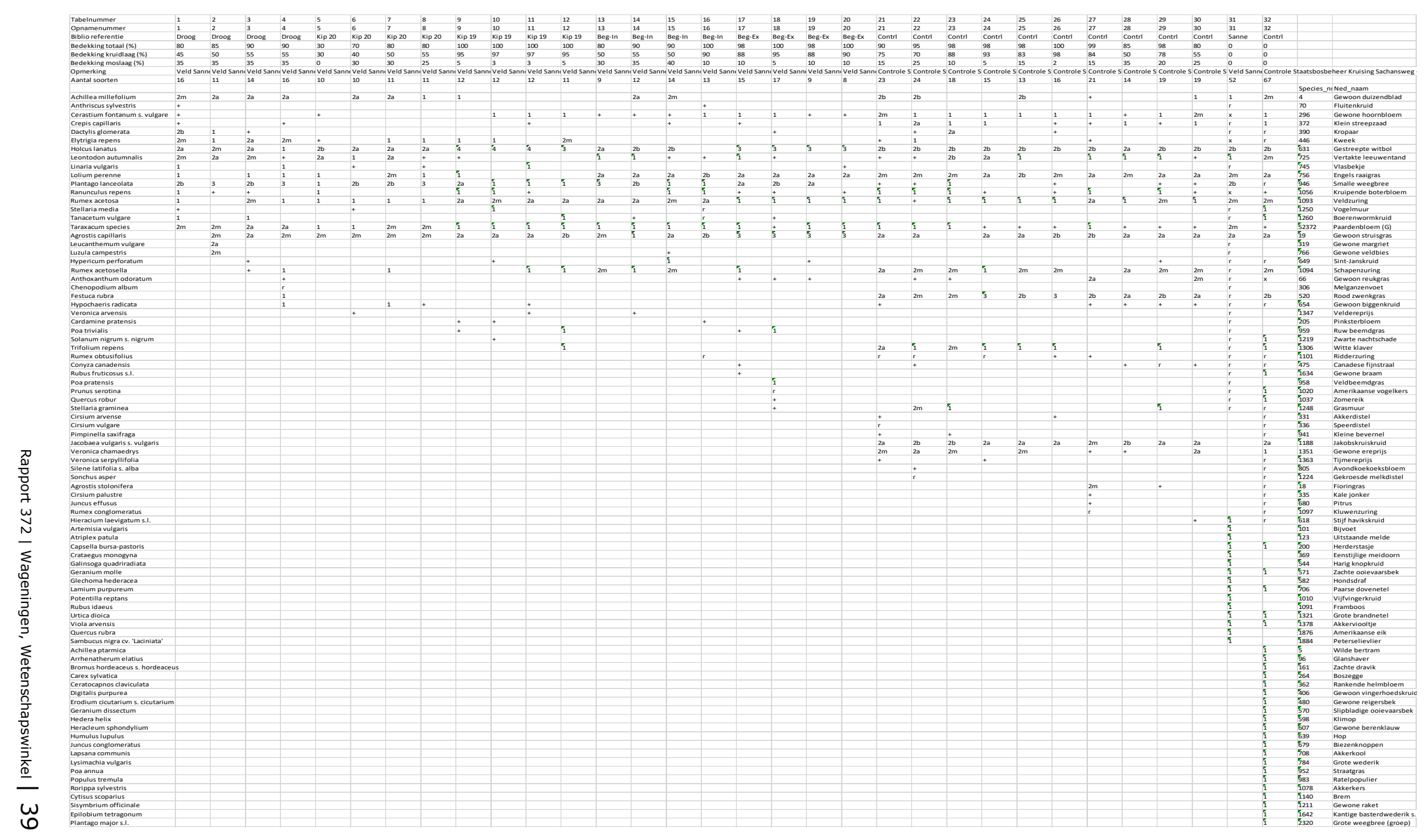


Bijlage 3 Bodemanalyses per monsterpunt en gemiddelde per behandeling

De data zijn goed leesbaar bij 400* vergroting. De gegevens zijn ook beschikbaar in een excel file, inclusief de figuren.

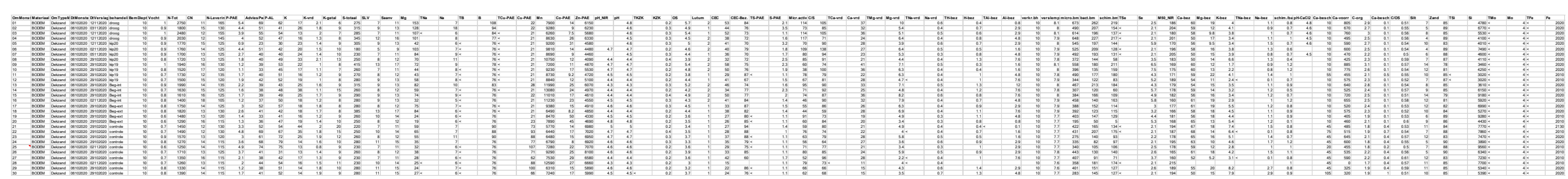

Gemiddelde van de monstername per behandeling en daaronder de standaarddeviatie.

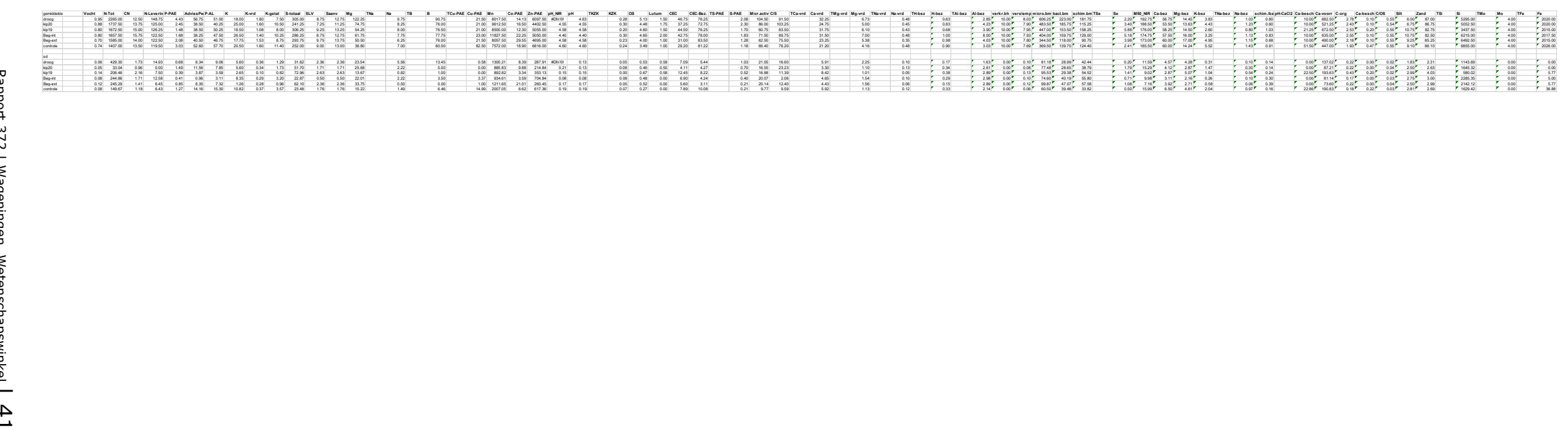




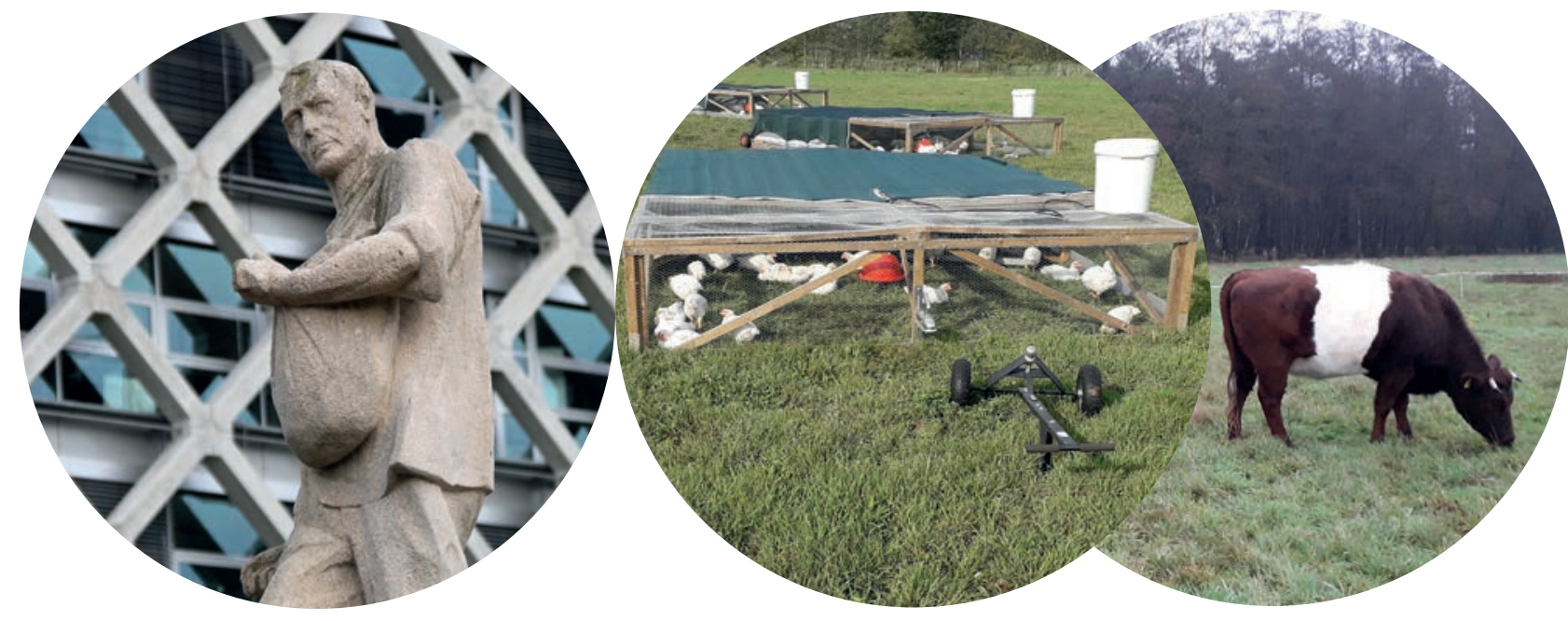

Wageningen University \& Research Wetenschapswinkel

Postbus 9101

6700 HB Wageningen

T (0317) 483908

E wetenschapswinkel@wur.nl

www.wur.nl/wetenschapswinkel
De missie van Wageningen University \& Research is 'To explore the potential of nature to improve the quality of life'. Binnen Wageningen University \& Research bundelen Wageningen University en gespecialiseerde onderzoeksinstituten van Stichting Wageningen Research hun krachten om bij te dragen aan de oplossing van belangrijke vragen in het domein van gezonde voeding en leefomgeving. Met ongeveer 30 vestigingen, 6.800 medewerkers ( $6.000 \mathrm{fte})$ en 12.900 studenten behoort Wageningen University \& Research wereldwijd tot de aansprekende kennisinstellingen binnen haar domein. De integrale benadering van de vraagstukken en de samenwerking tussen verschillende disciplines vormen het hart van de unieke Wageningen aanpak. 